Review

\title{
Bacterial coaggregation in aquatic systems
}

\author{
Ana C. Afonso ${ }^{a}$, Inês B. Gomes a, Maria José Saavedra ${ }^{b}$, Efstathios Giaouris ${ }^{c}$, \\ Lúcia C. Simões ${ }^{\mathrm{d}}$, Manuel Simões ${ }^{\mathrm{a}, *}$ \\ ${ }^{a}$ LEPABE, Faculty of Engineering, Department of Chemical Engineering, University of Porto, Porto, Portugal \\ ${ }^{\mathrm{b}}$ CITAB, Centre for the Research and Technology for Agro-Environment and Biological Sciences, University of Trás-os-Montes e Alto Douro, Vila Real, Portugal \\ ${ }^{c}$ Department of Food Science and Nutrition, School of the Environment, University of the Aegean, Ierou Lochou 10 E Makrygianni, Myrina 81400, Lemnos, \\ Greece \\ ${ }^{\mathrm{d}}$ CEB, Centre of Biological Engineering, University of Minho, Campus de Gualtar, Braga, Portugal
}

\section{A R T I C L E I N F O}

Article history:

Received 5 November 2020

Revised 7 March 2021

Accepted 8 March 2021

Available online 10 March 2021

\section{Keywords:}

Aquatic environments

Biofilms

Bridging organisms

Cell-to-cell adhesion

Interspecies coaggregation

Multispecies biofilms

\begin{abstract}
A B S T R A C T
The establishment of a sessile community is believed to occur in a sequence of steps where genetically distinct bacteria can become attached to partner cells via specific molecules, in a process known as coaggregation. The presence of bacteria with the ability to autoaggregate and coaggregate has been described for diverse aquatic systems, particularly freshwater, drinking water, wastewater, and marine water. In these aquatic systems, coaggregation already demonstrated a role in the development of complex multispecies sessile communities, including biofilms. While specific molecular aspects on coaggregation in aquatic systems remain to be understood, clear evidence exist on the impact of this mechanism in multispecies biofilm resilience and homeostasis. The identification of bridging bacteria among coaggregating consortia has potential to improve the performance of wastewater treatment plants and/or to contribute for the development of strategies to control undesirable biofilms. This study provides a comprehensive analysis on the occurrence and role of bacterial coaggregation in diverse aquatic systems. The potential of this mechanism in water-related biotechnology is further described, with particular emphasis on the role of bridging bacteria.
\end{abstract}

(c) 2021 Elsevier Ltd. All rights reserved.

\section{Introduction}

In natural aquatic environments bacterial cells are commonly encountered in close association with wet surfaces and interfaces in the form of multicellular aggregates, also known as biofilms (Romaní et al., 2016). These are defined as microbial aggregates in which cells are embedded in a self-produced matrix of extracellular polymeric substances (EPS) and are adhered to each other and/or to a surface (Vert et al., 2012). Inside these wellorganized structures the microorganisms are protected from environmental stresses, while ecological interactions among different species may occur (Christensen et al., 2002; Rao et al., 2005; Simões et al., 2007). In addition, physicochemical interactions can be established between microorganisms and inorganic particles (Evans, 2000; Fulaz et al., 2019). In fact, it is recognized that environmental biofilms are efficient binding matrices of inorganic particles (Ikuma et al., 2015).

Biofilms are crucial in the homeostasis of ecosystems and have an excellent ability to degrade and transform pollutants,

\footnotetext{
* Corresponding author.

E-mail address: mvs@fe.up.pt (M. Simões).
}

as they are involved in primary production (photosynthetic activity) (Underwood et al., 2005), carbon and nutrient cycling (Davey and O'Toole, 2000), retention of inorganic and organic nutrients (Pusch et al., 1998), and energy transfer in the food web (Feckler et al., 2015). Biofilms are also used for cleaning polluted water by removing organic material (Lazarova and Manem, 1995) as well as in other biodegradation processes (De Beer and Stoodley, 2006). On the other hand, biofilms may have negative effects, mainly in man-made systems (Table 1). Such effects include biofouling, the harbourage of pathogens and microbial induced corrosion, which may affect both industrial water (Videla and Herrera, 2005) and drinking water distribution systems (DWDS) (Simões and Simões, 2013). In marine systems, man-made structures such as aquaculture nets, oil and gas installations, and ship hulls are also affected by biofilms (Salta et al., 2013).

Biofilms are formed through a sequence of events that have been extensively described in several excellent comprehensive reviews (Hall-Stoodley and Stoodley, 2002; Verstraeten et al., 2008; Simões and Simões, 2013). Coaggregation is usually included in the biofilm formation process, being a widespread phenomenon already observed within several bacterial biofilm communities from diverse environments (Katharios-Lanwermeyer et al., 2014; 
Table 1

Benefits, problems and costs from biofilm formation in aquatic systems (adapted from de Carvalho, 2018; Mattila-Sandholm and Wirtanen, 1992).

\begin{tabular}{|c|c|c|c|}
\hline & Benefits & Problems & Estimated cost \\
\hline Aquaculture & $\begin{array}{l}\text { Reduce the occurrence of pathogenic } \\
\text { bacteria in culture system (e.g. nitrogen } \\
\text { uptake); Minimization of water exchange } \\
\text { (causes stress to some cultures) }\end{array}$ & $\begin{array}{l}\text { Fouling of both stock and infrastructures; } \\
\text { Biofouling on fish cages and shellfish } \\
\text { sites }\end{array}$ & $\begin{array}{l}1.5-3 \text { billion US dollars per year; } \\
5-10 \% \text { of the industry value in Europe } \\
\text { (ca. } 260 \text { million euros per year) }\end{array}$ \\
\hline $\begin{array}{l}\text { Drinking water } \\
\text { distribution } \\
\text { systems }\end{array}$ & $\begin{array}{l}\text { Act as biocatalysts in natural systems for } \\
\text { the self-purification of surface waters and } \\
\text { groundwater, and in engineered } \\
\text { fixed-film processes for the treatment of } \\
\text { DW and wastewater }\end{array}$ & $\begin{array}{l}\text { Increase power consumption in pumped } \\
\text { systems; } \\
\text { Material deterioration; Detachment of } \\
\text { microorganisms; } \\
\text { Water quality }\end{array}$ & $\begin{array}{l}\text { Billions US dollars per year in energy } \\
\text { losses, equipment damage, product } \\
\text { contamination and medical infections }\end{array}$ \\
\hline $\begin{array}{l}\text { Oil and gas } \\
\text { industry }\end{array}$ & & $\begin{array}{l}\text { Increase power consumption in pumped } \\
\text { systems; } \\
\text { Material deterioration; } \\
\text { Biocorrosion }\end{array}$ & $20-30 \%$ of corrosion-related costs \\
\hline $\begin{array}{l}\text { Maritime } \\
\text { transport }\end{array}$ & & $\begin{array}{l}\text { Heat transfer reduction; } \\
\text { Increase fuel consumption; } \\
\text { Material deterioration }\end{array}$ & $\begin{array}{l}35-50 \% \text { increased fuel consumption; } \\
1.6-4 \% \text { of annual operational cost for a } \\
\text { ship }\end{array}$ \\
\hline $\begin{array}{l}\text { Water } \\
\text { desalination }\end{array}$ & $\begin{array}{l}\text { Microbial desalination (environmentally } \\
\text { friendly technology) }\end{array}$ & $\begin{array}{l}\text { Biofouling accumulation reduces } \\
\text { effectiveness of ion exchange and } \\
\text { membrane processes used for } \\
\text { high-quality water treatment }\end{array}$ & $\begin{array}{l}5-20 \% \text { of operational costs for cleaning; } \\
\text { Cost of biofouling ca. } 30 \% \text { of total } \\
\text { operating costs }\end{array}$ \\
\hline
\end{tabular}

Stevens et al., 2015). Due to its highly specific mechanism of recognition and adhesion of different bacterial species to each other (Rickard et al., 2003a), it facilitates structural and metabolic codependences, subsequently contributing to the development of complex multispecies biofilm communities (Elliott et al., 2006). Coaggregation has been most thoroughly studied in oral biofilms (Kolenbrander et al., 2006). However, this phenomenon is also recognized as relevant for aquatic microbial systems (Dang and Lovell, 2016), not only for the establishement of complex sessile communities, but also for their protection from stress conditions, including disinfection (Simões et al., 2008). Several reports on the coaggregation ability of aquatic biofilm bacteria have been published (Buswell et al., 1997; Cheng et al., 2014; Gilbert et al., 2002; Ishii et al., 2005; Kwak et al., 2013; Malik et al., 2003; McCormick et al., 2011; Min and Rickard, 2009; Ramalingam et al., 2013; Rickard et al., 2004a, 2003b, 2000, 2004b; Simões et al., 2008; Stevens et al., 2015; Vornhagen et al., 2013). However, the data on coaggregation in aquatic systems is scarce, particularly when compared with the dental field. In fact, while several reviews (Jakubovics, 2015; Katharios-Lanwermeyer et al., 2014; Kolenbrander, 2000, 1993, 1988; Rickard et al., 2003a; Weiss et al., 1996) have examined the role of coaggregation among oral bacteria, only three reviews have addressed aspects of coaggregation in aquatic environments (Katharios-Lanwermeyer et al., 2014; McCormick et al., 2011; Rickard et al., 2003a). This study provides a comprehensive analysis on the occurrence and role of coaggregation in aquatic systems.

\section{Coaggregation}

Coaggregation is a highly specific cell-cell mechanism of recognition and adhesion of genetically distinct bacteria to each other (Rickard et al., 2003a), which is thought to have an essential role in the development of multispecies biofilms (KathariosLanwermeyer et al., 2014; Kolenbrander et al., 1999; Rickard et al., 2003a). This high-level interaction is beneficial for the microorganisms involved by providing a broader habitat range, effective cometabolism, increased resistance to host defenses, and enhanced virulence (Mahajan et al., 2013). Some other advantages include: the facilitated exchange of chemical signals and genetic information, protection from adverse environmental conditions as well as cell differentiation in some populations (Wimpenny and Colas- anti, 2004). The close proximity between coaggregating cells may facilitate the exchange of signals or cues that modulate cell-cell sensing and gene regulation (Mutha et al., 2019). For that reason, coaggregation has been suggested to lead profound phenotypic changes in the partner cells, enabling their proliferation in biofilms (Hendrickson et al., 2017; Mohammed et al., 2018; Mutha et al., 2018). These changes may be critical for adaptation and survival in multispecies biofilms (Mutha et al., 2019). Another advantage of the coaggregation mediated proximity is the possibility for extracellular electron transfer (Ishii et al., 2005, 2006; Summers et al., 2010), considered a promising strategy for diverse applications, including bioremediation, microbial fuel cells and microbial electrosynthesis (Kato, 2015; Shi et al., 2016).

Coaggregation can be established between multiple bacterial species (Buswell et al., 1997; Ramalingam et al., 2013; Rickard et al., 2002a), and is often strain-dependent (Buswell et al., 1997; Ramalingam et al., 2013; Rickard et al., 2002a; Simões et al., 2008; Vornhagen et al., 2013). Such phenomena were first recognized for oral plaque-forming bacteria by Gibbons and Nygaard (1970). These authors found that Streptococcus sanguis (now Streptococcus sanguinis) and Actinomyces naeslundii (now differentiated into three species - A. naeslundii, A. oris and A. johnsonii (Henssge et al., 2009)) were able to coaggregate strongly. Meanwhile, a large number of bacterial species from the oral cavity were found to have coaggregation ability (Jakubovics and Kolenbrander, 2010; Kolenbrander et al., 2002). Among them, Fusobacterium nucleatum presented a broad spectrum of such ability, being capable to coaggregate with multiple bacterial species, favouring biofilm development in the oral cavity and mediating the integration of pathogens into biofilms (Kolenbrander et al., 2002; Weiss et al., 2000) by acting as a bridging bacterium. This phenomenon has been observed among bacteria from aquatic environments (Buswell et al., 1997; Cheng et al., 2014; Ishii et al., 2005; Malik et al., 2003; Rickard et al., 2000, 2002a; Simões et al., 2008). Such bridging bacteria play an important role during multispecies biofilm development (Cheng et al., 2014; Simões et al., 2008).

As research progressed, techniques and systems to study coaggregation have been gradually improved in sensitivity and the ubiquity of this phenomenon begun to be appreciated in many research areas (McCormick et al., 2011). It was shown to occur between bacteria isolated from biofilms in the canine dental plaque (Cunha et al., 2020; Elliott et al., 2006; Holcombe et al., 2014), the 


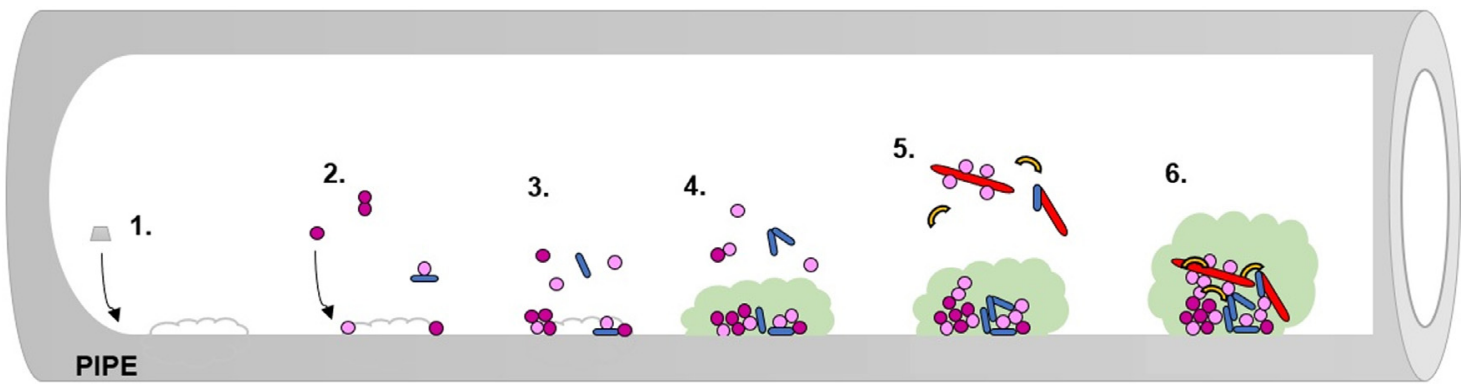

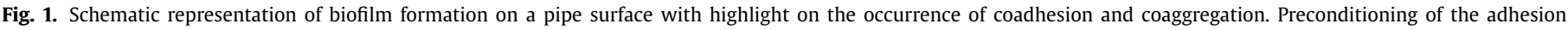

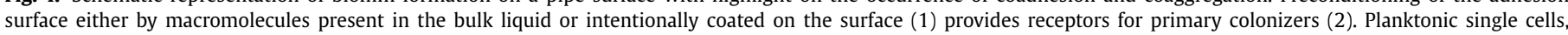

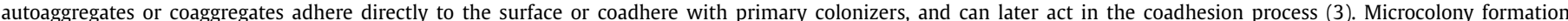

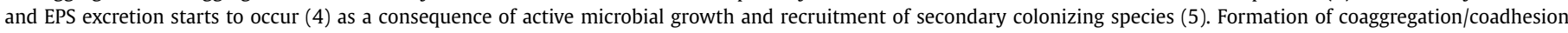

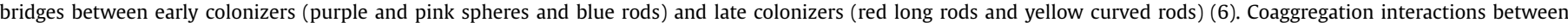

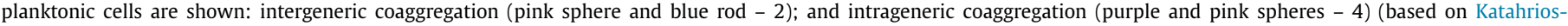
Lanwermeyer et al., 2014; Rickard et al., 2003a).

crop of chickens (Aziz et al., 2019; Nallala and Jeevaratnam, 2018), the human urogenital tract (Ekmekci et al., 2009; Younes et al., 2012), and in the human intestine (Ledder et al., 2008; Toh et al., 2019). In the last decades, coaggregation has also been reported for aquatic systems, including freshwater and wastewater biofilms (Buswell et al., 1997; Rickard et al., 2000; Simões et al., 2008).

\subsection{Coaggregation mechanisms}

Pre-conditioning of the adhesion surface by macromolecules present in the bulk liquid or intentionally coated on the surface is the first step in the successional development of multispecies biofilms, which increases the fixation of initial colonizing bacteria (Simões and Simões, 2013). This initial cell-surface interaction is mediated through specific or non-specific interactions (Marsh and Bradshaw, 1995). Non-specific interactions comprise physicochemical interactions between the bacterial cell envelope and material surfaces (e.g., van der Waals forces, electrostatic interactions, and hydrophobic effects). This is the first stage where adhesion is still reversible. The specific interactions contribute towards an irreversible adhesion (Carvalho et al., 2013). Specific interactions of bacteria with the colonizing surface are mediated by lectins and adhesins (Niemann et al., 2004), which bind to specific sites on host surfaces and materials (Katsikogianni et al., 2004). At this point, microorganisms have the ability to synthesize a variety of structural components, such as EPS, that help cells to fix on the surface material (Carvalho et al., 2013). There is a subsequent increase in biofilm cell density and species complexity due to the recruitment of secondary colonizers through coadhesion and nonspecific aggregation interactions (Bos et al., 1999; Busscher and van der Mei, 1997). Coaggregation contributes for biofilm development through the formation of networks of cell-cell interactions in suspension that will subsequently adhere on a surface by coadhesion (Fig. 1). Such interactions comprise the recognition of molecules on the surface of one cell by cognate surface components of genetically distinct cells. Coadhesion happens when the interaction occurs between suspended cells or coaggregates and cells adhered on a surface (Kolenbrander et al., 1997; Busscher and van der Mei, 1995; Bos et al., 1996).

Coaggregation is mediated by specific cell-surface polymers (Fig. 2) (Rickard et al., 2003a). These polymers are comprised of an adhesin (protein) on one partner and a receptor (saccharide containing polymer) on the other partner, referred to as unimodal coaggregation. Furthermore, one partner can express both adhesin and receptor, while the other partner cell expresses the respective cognates for the adhesin and receptor, referred to as bimodal coaggregation (Kolenbrander et al., 2010). In freshwater bacteria, co-

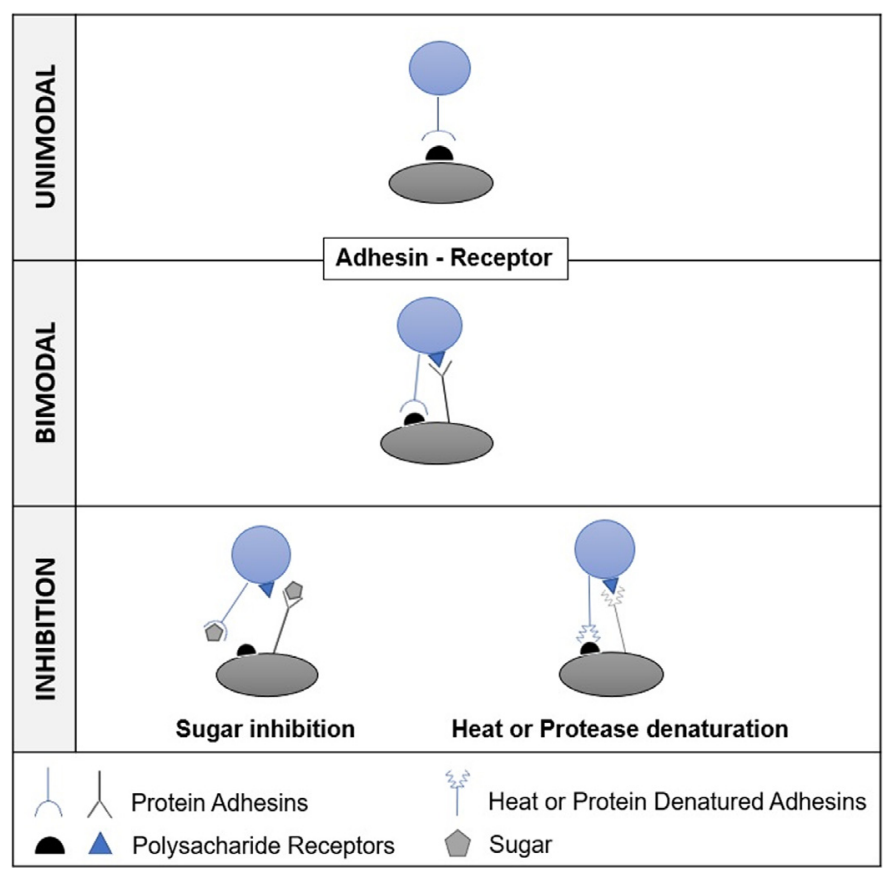

Fig. 2. Schematic representation of typical interactions between coaggregating pairs of bacteria and inhibition tests to assess the surface-associated molecules involved in coaggregation (based on Kolenbrander and Williams, 1981; Cisar et al., 1979).

aggregation has been found to be mediated by protein-saccharide and occasional protein-protein interactions (Rickard et al., 2003a; Kolenbrander, 2000). The surface-associated molecules involved in coaggregation are typically investigated by heat and protease treatment and sugar reversal tests. The inhibition or reversal of coaggregation is determined as a reduction in the coaggregation score (Cisar et al., 1979). Heat and protease treatment allows to demonstrate whether heat and protease-sensitive/insensitive proteins (lectins) mediate aggregation or not (Buswell et al., 1997). On the other hand, if coaggregation is reversed by adding one or more simple sugars to a suspension of coaggregating bacteria, this indicates that bacterial receptor molecules contain a carbohydrate moiety and that the interaction is mediated by lectinlike adhesins (Buswell et al., 1997). Several membrane-bound adhesins have been identified on the cell surfaces of dental plaque bacteria (Jakubovics and Kolenbrander, 2010; Kolenbrander, 2000). Until now, from a coaggregating biofilm bacterium not native to the oral cavity, only one coaggregation adhesin has been identi- 
fied (Rickard et al., 2002b). A protein of $70 \mathrm{kDa}$ with high sequence homology with a TonB-dependent receptor expressed by Caulobacter crescentus was isolated from the cell surface of the coaggregating freshwater biofilm bacterium Blastomonas natatoria 2.1 (Rickard et al., 2002b). It is suggested that this protein isolated from B. natatoria 2.1 is a TonB-dependent receptor protein that is also a coaggregation adhesin (Rickard et al., 2003a).

\subsection{Methodology to study coaggregation}

Coaggregation is usually assessed using a visual scoring scheme based on the size of the coaggregates and the resulting decrease of the turbidity of the supernatant fluid (Cisar et al., 1979; Gilbert et al., 2002; Vornhagen et al., 2013). The visual coaggregation assay involves the mixing of equal concentration/volume of planktonic bacteria (usually in pairs) followed by vigorous mixing in order to promote the contact and the recognition of mechanisms between cells, resulting in the formation of aggregates. The ability to coaggregate is then evaluated visually and scored from 0 (no coaggregation ability - absence of aggregates and turbid mixture) to 4 (large settling coaggregates formed rapidly leaving a clear supernatant). However, as visual scoring is subjective and only semi-quantitative, it is highly prone to inconsistency and bias in scoring (Busscher and van der Mei, 1995), compromising the comparison between studies. A spectrophotometric assay can be used to determine the percentage change in optical density (McIntire et al., 1978), which provides a quantitative assessment and greatly improves reliability and reproducibility. In this method, the absorbance of mixed planktonic bacteria is measured over time (at the beginning of the experiment and at selected time points). Through the absorbance values it is possible to determine the aggregation index (Kostelac et al., 2020; Malik et al., 2003). That method is not amenable for simultaneous screening of larger numbers of samples (Arzmi et al., 2015; Ledder et al., 2008). The ability to include multiple replicates in a single experiment is highly desirable, as there may be strain variation in coaggregation, requiring multiple crosses to determine if the observed phenomenon occurs generally between two species. Bacterial coaggregation is sensitive to a variety of parameters, such as growth phase of the cells (Rickard et al., 2000), temperature (Postollec et al., 2005), growth media (Min et al., 2010) and pH (Min et al., 2010). Therefore, high-throughput methods are highly attractive to improve reproducibility of results. To this direction, Levin-Sparenberg et al. (2016) developed a quantitative method for high-throughput screening of coaggregation among bacterial species. The method allows a simultaneous analysis of autoaggregation and coaggregation between large panels of strains so that the experimental variation is reduced, and possible subjective bias is minimized. It involves two complementary quantitative techniques to screen for coaggregation: i) a microplate-based highthroughput approach to analyze the absorbance of mixed cultures after 60 minutes; ii) a FlowCam ${ }^{\mathrm{TM}}$ device (a flow chamber coupled with an objective), which allows the determination of particle sizes through the acquisition of images throughout 10 minutes of flow experiment. The microplate-based assay enables high-throughput screening to identify potentially coaggregating strains, whereas the FlowCam-based assay validates and quantifies the extent of coaggregation. A high-throughput screening method can provide a deeper knowledge on how microorganisms interact and a mixed culture biofilm is formed.

Microscopy has also played an important role on the study of bacterial coaggregation. Even if semi-quantitative, microscopic analysis helps to understand coaggregation aspects not detected visually and/or and spectrophotometrically (Fig. 3). The simplest microscopic study of coaggregation refers to the evaluation of size and shape of coaggregates through phase-contrast micro- graphs by optical microscopy (Malik et al., 2003; Younes et al., 2012). The use of fluorescence microscopy using different fluorescence probes has also been applied to assess coaggregation between bacteria (Douterelo et al. 2014; Simões et al. 2008). For example, Simões et al. (2008) used a DNA binding stain, 4,6diamino-2-phenylindole (DAPI), to determine the coaggregation of bacteria isolated from drinking water through epifluorescence microscopy. Fluorescent probes may also be used in confocal laser scanning microscopy to visualize coaggregates and to identify different spatially distributed bacteria or microbial populations. Lukumbuzya et al. (2019) used a multicolor FISH (fluorescence in situ hybridization) approach to determine the spatial arrangement between different bacterial populations in activated sludge. Since FISH is a technique that requires fixation and hybridization steps, agarose is used to embed the cell aggregates and to reduce the impact of these two steps on the structure of aggregates. The spatial arrangement between two distinct populations were analyzed by a 3D "inflate algorithm" that quantifies the density of one microbial population at increasing distances from the cells of another population, as a measure of coaggregation. Almstrand et al. (2013) also applied a multicolor FISH approach in a confocal microscope to evaluate coaggregation of microbial populations within biofilms. An alternative method combining FISH with multispectral imaging (combinatorial labeling and spectral imaging [CLASI]-FISH) was developed (Almstrand et al., 2013; Valm et al., 2011) and used for coaggregation analysis. CLASI-FISH allowed simultaneous differentiation of up to 28 bacterial species within an oral biofilm (Olsen, 2018). Although bacterial coaggregation as well as ecological succession has been described in great detail for an oral biofilm, the micrometer-scale resolution needed to study the spatial organization of individual bacterial cells in the consortia is a limiting aspect (Attar, 2016). CLASI-FISH allowed the visualization of the biogeography of oral biofilms for the first time (Olsen, 2018), where it was possible to observe the specific location of particular bacteria, and with which species they tend to associate. This provided an analysis of the interaction and organization of microbial communities through combinational labeling and spectral imaging (Olsen, 2018). Therefore, its application in the study of coaggregation may be promising to understand the physiology and ecology of aquatic biofilm communities.

Flow cytometry (FCM) is a fast, robust and high-performance method for microbiological analysis (Geng and Henry, 2011). Scattered light gives an indication of the size of the particle, cell, or aggregate, whereas fluorescence can be used to differentiate between different microbial subpopulations (Trunk et al., 2018). Over the past few years, FCM has also been increasingly employed to investigate bacterial autoaggregation (Beloin et al., 2008; Tomich and Mohr, 2003). This suggests that FCM may also be used for coaggregation studies. For instance, Corno et al. (2013) studied the interaction between strains of two aquatic bacterial species (Arthrobacter agilis and Brevundimonas sp.) and a protistan predator by FCM.

Scanning electronic microscopy (SEM) has been used to visualize coaggregates and distinguish different bacteria in clusters (Cheng et al., 2014; Malik et al., 2003). The introduction of field emission SEM (FE-SEM) has allowed to obtain cleaner, high-quality and less electrostatically distorted images of samples (Cazaux, 2005). For example, Ishii et al. (2005) demonstrated that flagellum-like filaments produced by Pelotomaculum thermopropionicum SI were involved in coaggregation with Methanothermobacter thermautotrophicus $\Delta \mathrm{H}$. Atomic force microscopy (AFM) has also been proven useful to determine the interactive forces between coaggregating and non-coaggregating bacteria (Postollec et al., 2006; Vanzieleghem et al., 2016; Younes et al., 2012). Furthermore, molecular and genetic techniques have been used in the study of coaggregation. The isolation of mutants defective in genes associated with coaggregation have helped to define functions required 


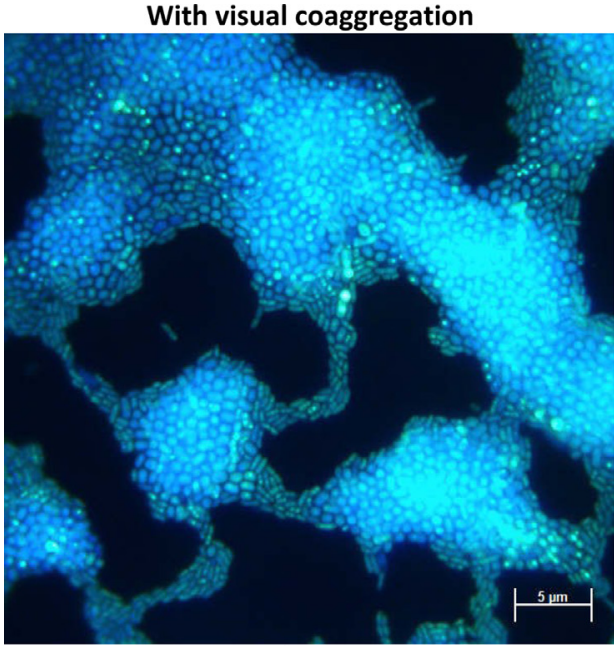

A. calcoaceticus/Burkholderia cepacia

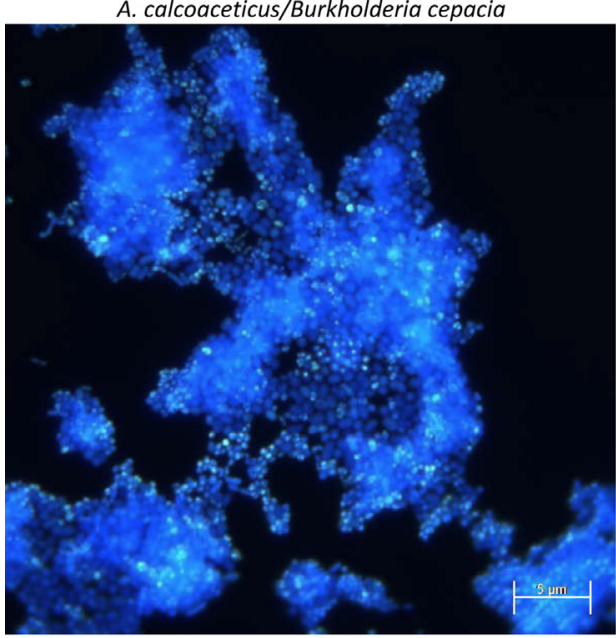

A. calcoaceticus/Staphylococcus sp.

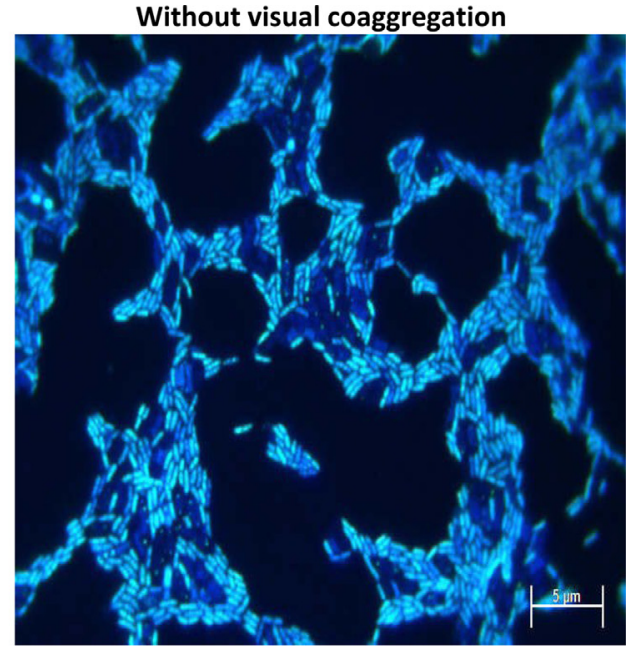

B. cepacia/Methylobacterium sp.

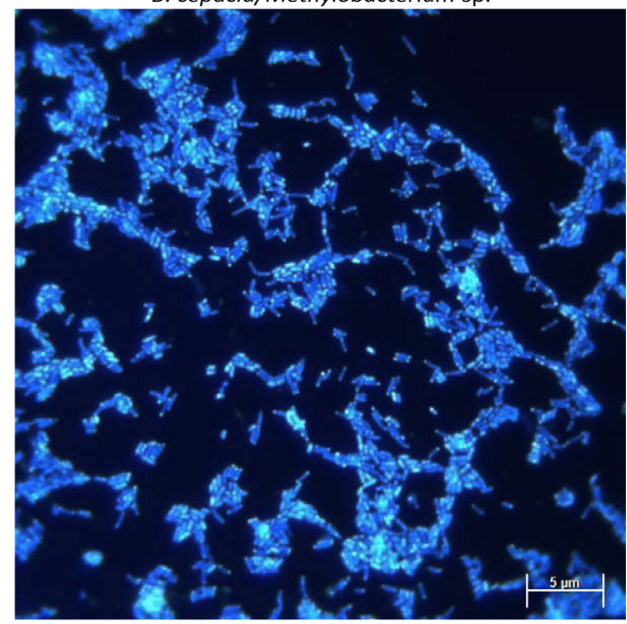

B. cepacia/M. mucogenicum

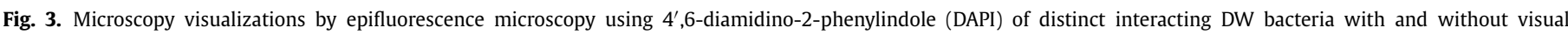

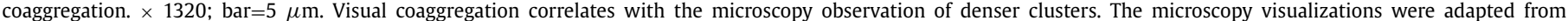
Simões et al. (2008) with permission from the American Society for Microbiology.

for intrageneric (between bacteria of the same genus) and intergeneric (between bacteria of different genera) coaggregation. These techniques are essential to determine bacterial structures and/or proteins that are crucial for the interaction between populations (Davey and O'Toole, 2000). Table 2 highlights the main advantages and limitations of methods used to study coaggregation.

Mathematical modelling and computational simulation have been playing an important role in the study of bacterial aggregates (Bondarenko et al., 2020; Kuan et al., 2020). Recently, Kuan et al. (2020) presented a theory to study the dynamics of bacterial aggregates, proposing a relevant of rheology in the merge of aggregates (Kuan et al. 2020). Rheological modeling approaches are important to provide theoretical insights to understand the rheological behavior of aggregates under distinct environmental conditions (Bondarenko et al., 2020).

\section{Coaggregation in aquatic systems}

The understanding of coaggregation in aquatic environments has potential to help managing microbiological-related problems: growth and retention of pathogens within biofilms in low and high shear environments; microbial induced corrosion; biofouling on surfaces; and increased resistance of bacteria to antimicrobials (Kerr et al., 2003). Furthermore, the application of coaggregation as a biotechnological technique to provide tailored microbiological communities has interest for the treatment of wastewater (Jiang et al., 2006; Khan et al., 2019; Li et al., 2013; Yue et al., 2018) and for aquaculture (as a probiotic) (García-Cayuela et al., 2014; Sánchez-Ortiz et al., 2015; Vadassery and Pillai, 2020; Zhang et al., 2013).

\subsection{Freshwater}

Coaggregation studies in freshwater environments evidenced its ecological role in the development and maintenance of multispecies biofilm communities (Rickard et al., 2003a). Coaggregation between freshwater bacteria have been observed between members of the same species (intraspecies coaggregation), between members of the same genus (intrageneric coaggregation) and between different genera (intergeneric coaggregation) (Rickard et al., 2003b, 2002a). Intraspecies (interstrain) coaggregation has only been described in freshwater, apparently related to the constantly changing environmental conditions and the possibility of contact between the resident biofilm bacteria with bacteria from other niches (Rickard et al., 2003b). In general, coaggregation in freshwater depends on different biotic and abiotic factors. Among the biotic factors, microbial growth phase (Rickard et al., 2000), expression of adhesin and receptors (Rickard et al., 2003b, 2000) or the production of EPS (Hede and Khandeparker, 2020) were found to influence coaggregation. Furthermore, the presence of 
Table 2

Methodologies to assess coaggregation and its main advantages and limitations.

\begin{tabular}{|c|c|c|c|c|}
\hline Methodology & Results & Advantages & Limitations & References \\
\hline Visual coaggregation & Semi-quantitative & Useful for initial screening & $\begin{array}{l}\text { Subjective; highly prone to } \\
\text { inconsistency and bias in } \\
\text { scoring; not amenable for a } \\
\text { larger number of samples }\end{array}$ & $\begin{array}{l}\text { (Cisar et al., 1979; } \\
\text { Gilbert et al., 2002; } \\
\text { Vornhagen et al., 2013) }\end{array}$ \\
\hline Spectrophotometry & Quantitative & Reliable; reproducible & $\begin{array}{l}\text { Not amenable for a larger } \\
\text { number of samples }\end{array}$ & (McIntire et al., 1978) \\
\hline $\begin{array}{l}\text { High throughput screening } \\
\text { method for coaggregation }\end{array}$ & Quantitative & $\begin{array}{l}\text { Simultaneous analysis of autoaggregation } \\
\text { and coaggregation; large number of } \\
\text { samples at the same time; low } \\
\text { variability; determines the particle size }\end{array}$ & $\begin{array}{l}\text { Involves two complementary } \\
\text { techniques }\end{array}$ & (Levin-Sparenberg et al., 2016) \\
\hline $\begin{array}{l}\text { Optical microscopy } \\
\text { (phase-contrast micrographs) }\end{array}$ & Semi-quantitative & $\begin{array}{l}\text { More sensitive than the visual and } \\
\text { spectrophotometric methods }\end{array}$ & $\begin{array}{l}\text { Only for the evaluation of size } \\
\text { and shape }\end{array}$ & $\begin{array}{l}\text { (Malik et al., 2003; } \\
\text { Younes et al., 2012) }\end{array}$ \\
\hline FISH & Quantitative & High sensitivity and specificity & $\begin{array}{l}\text { Short lifespan of the } \\
\text { fluorophore; limitations } \\
\text { associated with photostability; } \\
\text { lower power resolution than } \\
\text { SEM; limited number of } \\
\text { fluorophores }\end{array}$ & $\begin{array}{l}\text { (Almstrand et al., 2013; } \\
\text { Lukumbuzya et al., 2019) }\end{array}$ \\
\hline CLASI-FISH & Quantitative & $\begin{array}{l}\text { Quantitative analysis of microscopic } \\
\text { spatial relationships; simultaneous } \\
\text { differentiation of up to } 28 \text { bacterial } \\
\text { species within a biofilm; different } \\
\text { specific combinations of fluorophores }\end{array}$ & $\begin{array}{l}\text { Expensive equipment; available } \\
\text { in few laboratories }\end{array}$ & $\begin{array}{l}\text { (Almstrand et al., 2013; } \\
\text { Valm et al., 2011) }\end{array}$ \\
\hline FCM & $\begin{array}{l}\text { Qualitative and } \\
\text { Quantitative }\end{array}$ & $\begin{array}{l}\text { High-speed process; measure of sizes of } \\
\text { particles, cells, or aggregates; } \\
\text { differentiation in subpopulations; can be } \\
\text { used as an online monitoring tool }\end{array}$ & $\begin{array}{l}\text { Sophisticated data analysis; } \\
\text { relatively high detection limit } \\
\text { for certain bacteria }\end{array}$ & (Corno et al., 2013) \\
\hline SEM & $\begin{array}{l}\text { Qualitative and } \\
\text { Quantitative }\end{array}$ & $\begin{array}{l}\text { High resolution (detailed } \\
\text { three-dimensional and topographical } \\
\text { imaging) }\end{array}$ & $\begin{array}{l}\text { Cost; size; vacuum } \\
\text { environment; artefacts are } \\
\text { possible }\end{array}$ & $\begin{array}{l}\text { (Cheng et al., 2014; } \\
\text { Malik et al., 2003) }\end{array}$ \\
\hline FE-SEM & $\begin{array}{l}\text { Qualitative and } \\
\text { Quantitative }\end{array}$ & $\begin{array}{l}\text { Cleaner, high-quality, low-voltage, less } \\
\text { electrostatically distorted images; spatial } \\
\text { resolution down to } 1 \mathrm{~nm}\end{array}$ & Cost; size; vacuum environment & (Ishii et al., 2005) \\
\hline
\end{tabular}

solutes (Min and Rickard, 2009), the hydrodynamic conditions (Rickard et al., 2004b) and the environmental physicochemical properties (Min et al., 2010) are examples of abiotic factors impacting bacterial aggregation in freshwater.

Most coaggregation studies in aquatic environments have investigated biofilm bacteria isolated from freshwater, like boreholes and lakes (Buswell et al., 1997; Corno et al., 2014; Min et al., 2010; Min and Rickard, 2009; Rickard et al., 2003b, 2000). In a pioneer study, Buswell et al. (1997) demonstrated that coaggregation occurred between 19 freshwater strains isolated from a borehole. Rickard et al. found that coaggregation between 19 strains was mediated by growth-phase-dependent lectin-saccharide interactions (Rickard et al., 2000, 2002a). Coaggregation did not occur during exponential growth, whereas this was evident using cells in the stationary growth phase (Rickard et al., 2000). Maximum expression of coaggregation was maintained for up to $48 \mathrm{~h}$, keeping the stationary phase, being followed by a decrease and an eventual loss of coaggregation ability (Rickard et al., 2000). This 'on and off' switching could indicate that the expression of coaggregation adhesins and/or receptors is environmentally controlled through starvation and stress. On the contrary, dental plaque bacteria do not appear to exhibit such 'on and off' switching of the coaggregation phenotype (Katharios-Lanwermeyer et al., 2014; McCormick et al., 2011). Furthermore, coaggregation between freshwater bacteria was found to be mediated by adhesin-receptor and occasional adhesin-adhesin interactions (Rickard et al., 2003b, 2000). For example, Min et al. (2009) used galactosamine to determine whether it prevented Sphingomonas natatoria 2.1gfp cells from adhering on glass surfaces or on Micrococcus luteus 2.13 cells that covered glass surfaces. These authors suggested that galactosamine inhibits coaggregation by competing against the lectin binding sites on coaggregation adhesins, and that galactosamine plays an important role in mediating coaggregation between S. natatoria 2.1 and M. luteus
2.13. Min et al. (2009) proposed that S. natatoria 2.1 isolated from freshwater expresses coaggregation adhesins that enhanced biofilm integration and expansion, corroborating Rickard et al. (2000).

The variability of hydrodynamic conditions in freshwater environments can affect coaggregation and thereby contribute towards biofilm development or dispersal (McCormick et al., 2011). Different shear rates select for freshwater biofilms with different species composition and select for different proportions of intraspecies aggregating bacteria and coaggregation of bacterial species (McCormick et al., 2011). Rickard et al. (2004b) demonstrated that the magnitude of the shear rate can affect the relative proportion of aggregating bacteria in freshwater biofilms. The highest proportion of autoaggregating bacteria (aggregation of bacteria belonging to the same strain) was present at high shear rates (198-305 s $\left.\mathrm{s}^{-1}\right)$, while the highest proportion of coaggregating bacteria (bacteria of different strains or even different species) were observed under an intermediate shear rate

$\left(122 \mathrm{~s}^{-1}\right)$.

Physicochemical properties such as ionic strength, $\mathrm{pH}$, temperature and viscosity can affect coaggregation between freshwater bacteria (Min et al., 2010). S. natatoria 2.1 and M. luteus 2.13 were found to have lower coaggregation ability in an oral bacterial coaggregation buffer, saline solution and in Tris- $\mathrm{Cl}$ buffer than in distilled water (Min et al., 2010). Also, coaggregation was weakly expressed in standard laboratory buffers (including HBS and PBS) (Min et al., 2010). Furthermore, coaggregation occurred at a $\mathrm{pH}$ of $3-10$, between 5 and $80^{\circ} \mathrm{C}$, and was inhibited in solutions with viscosity of 22.5 centipoises, at $20^{\circ} \mathrm{C}$ (Min et al., 2010). Therefore, the ideal conditions for coaggregation to occur may differ significantly between bacteria from different environments, and the use of buffers that resemble the environmental conditions from which the bacteria were isolated seems to be appropriate for the effective detection of coaggregation. 
EPS also mediate the coaggregation of aquatic biofilm-forming bacteria (Hede and Khandeparker, 2020). Freshwater, estuarine and marine biofilm bacteria were evaluated for aggregation, and their cell-bound EPS (CB-EPS), known to play an important role in biofilm formation, were characterized (Hede and Khandeparker, 2020). The biofilm forming potential via coaggregation of estuarine and freshwater biofilm bacteria was higher. This was attributed to CB-EPS rich in carbohydrates with distinct sugar composition, compared with that produced by the bacteria from the marine biofilm. Most of the biofilm bacteria lost their ability to coaggregate after removal of CB-EPS. Estuarine (Bacillus indicus and $B$. cereus) and freshwater (Exiguobacterium spp. and B. cereus) bacterial pairs, retained their aggregation ability suggesting the expression of specific biomolecules, apparently lipids and proteins, under stress conditions (Hede and Khandeparker, 2020).

Coaggregation has been suggested as a successful strategy for antibiotic resistance in aquatic bacterial communities (Corno et al., 2014). Corno et al. (2014) studied the response of a freshwater bacterial community (isolated from European lakes) to the presence of antibiotics under low (12.5 $\left.\mu \mathrm{g} . \mathrm{L}^{-1}\right)$ and high (125 $\left.\mu \mathrm{g} . \mathrm{L}^{-1}\right)$ doses. They observed that bacterial abundance rapidly decreased by $75 \%$ in the presence of antibiotics, regardless the concentration, and remained constant until the end of the experiment (after 25 days). By investigating the phenotypic adaptation of the communities subjected to the different treatments, these authors found that the presence of antibiotics significantly increased coaggregation by 5-6 fold. The complexity of the interactions within the clustered cells increased enormously, resulting in the formation of a specific microenvironment where the resistance of the single bacterial cells against antibiotic rose, due to proximity and species interactions. Moreover, bacteria in aggregates are surrounded by different forms of self-synthetized hydrated EPS, effectively reducing the diffusion of the antibiotic due the reduced permeability of the aggregate itself. Therefore, coaggregation can represent a survival strategy for planktonic bacteria when exposed to environmental concentrations of antibiotics (Corno et al., 2014, 2013). Sub-inhibitory concentrations of antibiotics can act as signaling molecules, mediating a wide variety of cellular processes such as gene transcription and expression, quorum sensing, inter or intraspecies communication, biofilm formation, and might accelerate horizontal gene transfer (Andersson and Hughes, 2014; Davies et al., 2006; Sengupta et al., 2013).

\subsection{Drinking water}

There is a significant lack of information regarding the role of coaggregation in DW environments, namely its role in DW biofilm development. A search in SCOPUS (January 2021) filtered using the keywords: "Coaggregation"; "Drinking Water" in the title, keywords and abstract only displayed four items: two describing the coaggregation phenomena in DW bacteria (Ramalingam et al., 2013; Simões et al., 2008), one review (Reuben et al., 2019) and another regarding coaggregation in freshwater (Rickard et al., 2004b). Although the lack of research regarding coaggregation in DW, there is a consensus among the existing studies on the impact of coaggregation in biofilm development (Ramalingam et al., 2013; Simões et al., 2008; Vornhagen et al., 2013). Simões et al. (2008) described the intergeneric coaggregation of six heterotrophic bacteria isolated from DW and investigated the nature of surface molecules involved in the coaggregation process. These authors presented Acinetobacter calcoaceticus as a bridging bacterium, able to coaggregate with four (Burkholderia cepacia, Mycobacterium mucogenicum, Sphingomonas capsulata, and Staphylococcus sp.) of the five DW bacteria, with the exception of Methylobacterium sp.. A. calcoaceticus interactions were found to be lectin-saccharide mediated.
Simões et al. (2008) also demonstrated that the bridging function of A. calcoaceticus was positively correlated with multispecies biofilm formation. Ramalingam et al. (2013) investigated autoaggregation, coaggregation and biofilm formation of bacteria belonging to four different genera (Sphingobium, Xenophilus, Methylobacterium and Rhodococcus) isolated from DW. That work highlighted coaggregation of the bacteria as a result of time-dependent species-specific interactions. Additionally, the authors reported the strong impact of coaggregation in biofilm development by the DW bacteria. In the work of Vornhagen et al. (2013) it was demonstrated that coaggregation occurred between bacteria isolated from domestic showerheads. They suggested coaggregation as a common feature in showerhead biofilms after identifying 31 distinct bacterial genera per biofilm (from three distinct showerheads). Vornhagen et al. (2013) highlighted the genera Brevundimonas, Micrococcus and Lysobacter as those with higher ability to coaggregate with isolates from a different showerhead biofilm (inter-biofilm coaggregation) and from the same showerhead biofilm (intra-biofilm coaggregation).

In fact, a concept has emerged in the formation of multispecies DW and freshwater biofilms: the "bridging organisms" (Buswell et al., 1997; Ramalingam et al., 2013; Rickard et al., 2002a; Simões et al., 2008; Vornhagen et al., 2013). These typically display a broad spectrum coaggregation ability, allowing coaggregation with multiple bacterial species, enhancing the development of multispecies biofilms, and mediating the integration of pathogens into the biofilms (Cheng et al., 2014; Ramalingam et al., 2013). Table 3 provides details on the bacteria reported so far for their bridging behavior in DW systems. Simões et al. (2008) demonstrated that A. calcoacticus facilitated the association of the other species that do not coaggregate directly with each other, increasing the metabolic cooperation. For that, biofilms were developed at different bacterial combinations through a strain exclusion process. The authors noted that biofilm mass over time (24h, $48 \mathrm{~h}$ and $72 \mathrm{~h}$ ) increased for all combinations, except for multispecies biofilms without $A$. calcoaceticus. The presence or the absence of $A$. calcoaceticus in multispecies biofilms enhanced or decreased, respectively, biofilm mass formation by DWisolated bacteria. This suggests that $A$. calcoaceticus may behave as a bridging microorganism like the oral bacterium $F$. nucleatum (Katharios-Lanwermeyer et al., 2014). Min et al. (2009) raised the question on whether DW or freshwater bridging bacteria, such as A. calcoaceticus and S. natatoria, can aid the retention of pathogens or if the ability to coaggregate with specific species (i.e., bridge) is a mechanism to outcompete other species in multispecies biofilms. In the case of $S$. natatoria 2.1gfp, the findings suggest that the ability to coaggregate and act as a bridge enhanced multispecies biofilm biomass production. However, unlike $A$. calcoaceticus, which seemingly favored the expansion of all species in the mixed community, S. natatoria $2.1 \mathrm{gfp}$ numerically dominated at the expense of other species in the biofilm. In addition, the concept of bridging seems to explain the resistance of multispecies consortia to disinfection, namely to sodium hypochlorite $(\mathrm{NaOCl})$ (Simões et al., 2010). Simões et al. (2010) assessed the susceptibilities to $\mathrm{NaOCl}$ of single and multispecies biofilms formed by six DW-isolated bacterial species, A. calcoaceticus, B. cepacia, Methylobacterium sp., M. mucogenicum, S. capsulata, and Staphylococcus sp. The authors observed that multispecies biofilms were more resistant to inactivation and removal than the relevant monospecies biofilms. They further observed that biofilms containing all bacteria had the highest resistance to $\mathrm{NaOCl}$, while those without $A$. calcoaceticus were the most susceptible, denoting that the presence of that latter species in the multispecies biofilms increased resistance to disinfection. Such result was attributed to the the role of $A$. calcoaceticus as a bridging bacterium in the microbial community. In fact, bridging may facilitate stronger EPS formation resulting in diffusion limita- 
Table 3

Bridging bacteria from different aquatic environments and their coaggregating pairs.

\begin{tabular}{|c|c|c|c|}
\hline Bridging bacteria & Pairs & Source & Reference \\
\hline Micrococcus luteus & $\begin{array}{l}\text { Pseudomonas pickettii } \\
\text { Methylobacterium spp. } \\
\text { Brevundimonas vesicularis }\end{array}$ & Aquatic biofilm & (Buswell et al., 1997) \\
\hline Sphingomonas natatoria 2.1 & $\begin{array}{l}\text { Afipia sp. } 2.2 \\
\text { S. natatoria } 2.3 ; 2.4 ; 2.5 ; 2.6 \\
\text { Methylobacterium sp. } 2.7 ; 2.9 \\
\text { M. luteus } 2.13 \\
\text { Nocardioides sp. } 2.14 ; 2.20 \\
\text { P. marcusii } 2.21 \\
\text { Pseudomonas sp. } 2.10 ; 2.11 ; 2.12 ; 2.15 ; 2.18\end{array}$ & Freshwater & (Rickard et al., 2002a) \\
\hline Acinetobacter calcoaceticus & $\begin{array}{l}\text { Mycobacterium mucogenicum } \\
\text { Burkholderia cepacia } \\
\text { Methylobacterium sp. } \\
\text { Sphingomonas capsulata } \\
\text { Staphylococcus sp. }\end{array}$ & Drinking water & (Simões et al., 2008) \\
\hline Acinetobacter johnsonii & $\begin{array}{l}\text { Xanthomonas sp. S11; S53; S54 } \\
\text { O. carboxidovorans S23; S28 } \\
\text { M. esteraromaticum S29; S38; S51 } \\
\text { A. junii S33 }\end{array}$ & Sewage (activated sludge) & (Malik et al., 2003) \\
\hline $\begin{array}{l}\text { Brevundimonas lenta HM006 } \\
\text { Micrococcus luteus AH004 } \\
\text { Lysobacter gummosus HM010 }\end{array}$ & $\begin{array}{l}17 \text { unspecified strains } \\
17 \text { unspecified strains } \\
14 \text { unspecified strains }\end{array}$ & $\begin{array}{l}\text { Drinking water } \\
\text { (showerheads) }\end{array}$ & (Vornhagen et al., 2013) \\
\hline Methylobacterium & $\begin{array}{l}\text { Spingobium sp. } \\
\text { Xenophilus sp. } \\
\text { Rhodococcus sp. }\end{array}$ & Drinking water & (Ramalingam et al., 2013) \\
\hline $\begin{array}{l}\text { Bacillus cereus G5 } \\
\text { Bacillus megaterium } \mathrm{T} 1\end{array}$ & $\begin{array}{l}19 \text { unspecified strains } \\
17 \text { unspecified strains }\end{array}$ & $\begin{array}{l}\text { Sewage; Pond stones; } \\
\text { Industrial wastewater }\end{array}$ & (Cheng et al., 2014) \\
\hline
\end{tabular}

tions (Sanchez-Vizuete et al., 2015). However, the specific mechanism for this remains unknown. A more complete picture of interspecies relationships would help to understand bacterial resistance to disinfectants and contribute to the development of innovative and effective control strategies to guarantee the microbiological safety of DW (Simões and Simões, 2013).

\subsection{Wastewater}

Several technologies are used in wastewater treatment plants (WWTPs) whose efficiency is highly dependent on bacterial coaggregation (Malik et al., 2003). For instance, bacterial (co)aggregation is a primary step towards biofilm development, flocculation of activated sludge and aerobic granulation in WWTPs - these processes depend on the ability to produce granules and biofilms containing microorganisms able to degrade pollutants (Malik et al., 2003). The anthropogenic release of large amounts of nitrogen is a pervasive and serious environmental problem (i.e. eutrophication) (Diaz and Rosenberg, 2008). Besides agriculture, sewage is one of the largest sources of inorganic nitrogen, in particular ammonia from urea degradation (Lücker et al., 2015). Most WWTPs exploit nitrifying and denitrifying microorganisms to oxidize ammonia via nitrite to nitrate (nitrification) and to subsequently reduce the produced nitrate to gaseous dinitrogen (denitrification) (Lücker et al., 2015). Complete nitrification depends on the mutualistic interaction of ammonia-oxidizing bacteria (AOB) and nitrite-oxidizing bacteria (NOB) (Gujer, 2010; Wagner et al., 2002). Coaggregation of AOB and NOB in nitrifying activated sludge and biofilm samples is observed frequently for Nitrospira with various AOB (Daims et al., 2001; Gruber-Dorninger et al., 2015; Lücker et al., 2015). Similarly, AOB and AnAOB (anaerobic ammonium oxidizing bacteria) coaggregate in partial nitrification anammox systems (Gizem, 2015). Malik et al. (2003) explored the possibility of intergeneric coaggregation among 32 strains of nonflocculating bacteria isolated from activated sludge from a munici- pal sewage treatment plant. They found that eight strains coaggregated with Acinetobacter johnsonii S35 while only four strains coaggregated moderately with Acinetobacter junii S33. Both strains of those latter species were able to coaggregate with bacteria from various genera. The study suggests the possibility of developing multi-generic coaggregates with Acinetobacter isolates as bridging microorganisms, as proposed by Simões et al. (2008) with A. calcoaceticus in DW systems. It further highlights the role of nonflocculating bacteria for floc formation in activated sludge.

Wastewater activated sludge is known to be composed by naturally occurring microorganisms that biodegrade a wide range of pollutants. However, some pollutants are not biodegradable (Nzila et al., 2016). Therefore, other technologies have been identified as viable options for the treatment of high-strength industrial effluents, including those containing toxic and/or recalcitrant compounds (Khan et al., 2019). For example, the immobilization of degrading-bacteria in biofilms has been suggested as a strategy for maintaining efficient biodegradation in a bioaugmentation system (Li et al., 2013). This strategy has advantages over traditional approaches, such as tolerance to hostile environments, proliferation of the immobilized bacteria and the low cost for immobilization (Cheng et al., 2014). Kwak et al. (2013) reported that Sphingomonas sp. 224 co-inoculated with the biofilm-forming bacteria Pseudomonas sp. C7 and Bacillus sp. E5 degraded tolclofosmethyl more effectively than Sphingomonas sp. 224 alone. Jiang et al. (2006) found that Comamonas sp. PG-08 had enhanced phenol degradation when coaggregate with Propioniferax-like PG-02. Additionally, the coaggregation of some Bacillus species improved the ability of other bacterial species to degrade specific pollutants (Adav et al., 2008; Di Gioia et al., 2004). For example, Bacillus thuringiensis I2 had augmented degradation of phenol when coaggregated with A. calcoaceticus I6 (Adav et al., 2008). Furthermore, Bacillus VA160 also improved the ability of Acinetobacter BCaL1 and Stenotrophomonas BCaL2 to degrade polyethoxylated nonyphenols (Di Gioia et al., 2004). Yue et al. (2018) proposed that bioaug- 
mentation of $p$-nitrophenol (PNP) degradation was as a result of adding a novel PNP-degrading bacterium, Methylobacterium sp. $\mathrm{C} 1$, which coaggregated with two broad-spectrum coaggregating strains (Bacillus megaterium T1 or Bacillus cereus G5) from WWTPs. These authors found that biofilms containing coaggregating bacteria (Bacillus megaterium T1 or Bacillus cereus G5) were able to immobilize degrading bacteria (such as Methylobacterium sp. C1), conferring them protection against external unfavorable conditions. Such process resulted in the formation of biofilms able to protect PNP degrading strains from washing out, improving the overall PNP degradation (Yue et al., 2018).

Aerobic granulation is a technological approach alternative to traditional water treatment methods (de Kreuk and van Loosdrecht, 2006). Aerobic granules are auto-immobilized microspheres containing different microbial species (Sarma and Tay, 2018). Aerobic granulation is initiated and driven by hydraulic selection pressure, such as short settling time, to select and retain compact microbial aggregates and wash out light and dispersed particles (Liu et al., 2005). Under these selection pressures, cell aggregation - including autoaggregative and coaggregative interactions, might be promoted for aerobic granules formation (Jiang et al., 2006). Research on the occurrence of coaggregation in aerobic granulation would help to uncover putative mechanisms to favour the granulation process, particularly the selection of specific microorganisms. Jiang et al. (2006) investigated the effect of bacterial coaggregation on aerobic granulation through bioaugmentation by Propioniferax-like PG-02 and Comamonas sp. PG-08. PG-02 (a phenol-degrader with a low half-saturation kinetic constant) and PG-08 (strong aggregator with poor phenol degradation ability) coaggregated through lectin-saccharide interactions with the adhesin protein on PG-02 and the complementary sugar receptor on PG-08. When incubated together, these strains cooperated in phenol degradation. These authors concluded that bioaugmentation with both strains simultaneously significantly improved phenol removal and aerobic granulation in sequencing batch reactors. Adav et al. (2008) explored the intergeneric coaggregation of A. calcoaceticus I6 and Bacillus thuringiensis I2 or Candida tropicalis 19 isolated from phenol-degrading aerobic granules. The protease or heat treatment reduced the coaggregation ability of strain I6, showing the presence of adhesins on its surface for coaggregation. The treatment using simple sugars demonstrated that coaggregation between strains $\mathrm{I} 6+\mathrm{I} 2$ and $\mathrm{I} 6+\mathrm{I} 9$ was mediated by a lectin-saccharide interaction. This corroborates the study of Jiang et al. (2006) on the formation of phenol-degrading granules. Khan et al. (2019) investigated the application of aerobic granules towards degradation of the target contaminant sulfolane. Pregrown acetate fed granules and microbial communities native to sulfolane contaminated sites were used as the basis for the cultivation of new aerobic granules. The newly formed coaggregated granules had different morphological appearance in contrast to pre-grown acetate fed granules. In particular, the surface of new granules was covered with filamentous bacteria that provided protection and stability. The new aerobic granules were shown to be robust and stable over prolonged exposure to various environmental conditions and displayed intact structure with good settling abilities.

\subsection{Marine waters}

Although research of coaggregation partnerships have scarcely been undertaken with marine bacteria (Ishii et al., 2005; SánchezOrtiz et al., 2015; Zhang et al., 2013), coaggregation-based cellcell interactions seem to play an important role in biofilm formation in marine environments as in freshwater ones (KathariosLanwermeyer et al., 2014; McCormick et al., 2011). Coaggregation in marine environments was reported as dependent on the growth substrate (Ishii et al., 2005) - bacteria can coaggregate due to metabolic advantage. Ishii et al. (2005) observed that Pelotomaculum thermopropionicum SI and $M$. thermautotrophicus $\Delta \mathrm{H}$ coaggregated when in a syntrophic coculture, and coaggregation was dependent on the growth substrate (propionate, ethanol or 1propanol). These authors suggested that coaggregation was established to achieve an efficient $\mathrm{H}_{2}$ flow between species, favoring energetically the syntrophic oxidation of propionate. Furthermore, Ishii et al. (2005) demonstrated that flagellum-like filaments produced by strain SI were involved in coaggregation.

Aquaculture, probably the fastest growing part of agriculture worldwide, accounts for nearly 50 percent of the world's food fish (FAO, 2017). Because of the rapid and enormous expansion of that industry, methods for culture have become more intensive (Rico et al., 2012). However, huge losses of production in aquaculture are microbiological-related. Infectious diseases in aquaculture are the most serious constraint causing multibillion-dollar loss annually while potentially endangering the consumers' health (Assefa and Abunna, 2018). Microbial interactions can provide a reliable strategy to control pathogens. In particular, lactic acid bacteria (LAB) are generally used as the probiotics in aquaculture (Verschuere et al., 2000). LAB are characterized for their ability to coaggregate and autoaggregate, an inhibition effect on the growth of pathogens and a reduced antibiotic resistance (to prevent lateral spread of resistance) (Giaouris, 2020; Vadassery and Pillai, 2020). The ability for a probiotic to aggregate within the gastrointestinal (GI) tract is a desirable characteristic and can be used for initial evaluation and selection of the best probiotic strain (García-Cayuela et al., 2014; Vadassery and Pillai, 2020). Such adhesion ability may result in the formation of a barrier to prevent later colonization by pathogens (Del Re et al., 2000), and constitute an important host defense mechanism (Rickard et al., 2003a). Also, when probiotics coaggregate with pathogens, a facilitated removal of pathogens from the GI environment is likely to occur (García-Cayuela et al., 2014). Diverse studies examined the possibility of coaggregation between marine pathogens and LAB (Sánchez-Ortiz et al., 2015; Vadassery and Pillai, 2020; Zhang et al., 2013). Zhang et al. (2013) isolated and identified a LAB strain (Leuconostoc lactis) from the intestine of the black porgy fish. That strain was able to coaggregate with diverse fish pathogens: Vibrio parahaemolyticus, Listeria monocytogenes, Shigella, Staphylococcus aureus, Proteus vulgaris, Escherichia coli and Salmonella Typhimurium. In vitro tests demonstrated an inhibitory effect on the growth of pathogens, low antibiotic resistance and ability to coaggregate with pathogens. Sánchez-Ortiz et al. (2015) characterized the probiotic action of LAB strains isolated from the bivalve Anadara tuberculosa as suitable for shrimp farming. The highest coaggregation with the fish pathogens was found for Staphylococcus sp. followed by Bacillus licheniformis and B. subtilis ssp. subtilis. Also, in order to prove the probiotic potential of the selected bacteria, the authors performed an in vivo assay by introducing the strains in the whiteleg shrimp (Litopenaeus vannamei) diet. In general, LAB strains demonstrated beneficial effects on the growth and immune response of L. vannamei. Vadassery \& Pillai (2020) isolated Enterococcus faecium QQ12 from the GI tract of Nile tilapia (Oreochromis niloticus) and assessed their ability as a probiotic to control Aeromonas hydrophila infection in the goldfish Carassius auratus. Here, the main objective of the study was to assess the disruption of quorum sensing signaling molecules by quorum quenching (QQ), as an effective strategy to control virulence. However, other probiotic properties were assessed, and the capability of $E$. faecium QQ12 to adhere on the intestinal cell wall was evaluated by autoaggregation and coaggregation assays. The results showed that, in addition to excellent QQ properties, E. faecium exhibited very good co-aggregation ability after $5 \mathrm{~h}$ of incubation with $A$. 
hydrophila, during which more than $50 \%$ of E. faecium population co-aggregated with A. hydrophlila.

\section{Conclusions}

The resurgent role of multispecies microbial communities in several research fields and the recent advances in multidisciplinary approaches for their study provide an increased interest on understanding the role of coaggregation in the establishment and behavior of sessile communities. While the ubiquitous presence of biofilms in aquatic systems is widely recognized, autoaggregation and coaggregation have also been described for bacteria from freshwater, drinking water, wastewater and marine water. The current knowledge on coaggregation in these aquatic systems proposes that this mechanism may provide selective advantages to the bacteria over the non-coaggregating counterparts, playing an important ecological role in the development and maintenance of multispecies biofilms, including their resistance to antimicrobials. Coaggregation is strain specific, i.e. depends on the strain ability to express specific cell surface molecules, and relies on the existence of adequate physiological and environmental conditions to occur. However, the molecular mechanisms of coaggregation by bacteria grown in aquatic systems remain to be explored. The study of coaggregation and the identification of bridging bacteria will contribute to further understand the robust establishment of sessile communities. Bridging bacteria, with broad-spectrum coaggregation ability, appear to play an important role in multispecies biofilm development and behavior. The exploitation of bridging bacteria for biotechnological applications in aquatic systems has potential to improve the performance of wastewater treatment plants using activated sludge/flocs, granules and biofilm-based reactors as well as for the development of refined strategies targeting these key microorganisms for an efficient control of pathogens and undesirable biofilms.

\section{Declaration of Competing Interest}

Authors declare no conflict of interests.

\section{Acknowledgements}

This work was financially supported by: Base FundingUIDB/00511/2020 of LEPABE and UIDB/00081/2020 of CIQUP funded by national funds through the FCT/MCTES (PIDDAC); Project Biocide_for_Biofilm-PTDC/BII-BTI/30219/2017-POCI-01-0145-FEDER030219, ABFISH-PTDC/ASP-PES/28397/2017-POCI-01-0145-FEDER028397 and ALGAVALOR-POCI-01-0247-FEDER-035234, funded by FEDER funds through COMPETE2020-Programa Operacional Competitividade e Internacionalização (POCI) and by national funds (PIDDAC) through FCT/MCTES. This study was further supported by the Portuguese Foundation for Science and Technology (FCT) under the scope of the strategic funding of UIDB/04469/2020 unit and BioTecNorte operation (NORTE-01-0145-FEDER-000004) funded by the European Regional Development Fund under the scope of Norte2020 - Programa Operacional Regional do Norte. The authors also thank to CITAB (Centre for the Research and Technology of Agro-Environmental and Biological Sciences) under the scope of the FCT funds with reference UIDB/AGR/04033/2020. Ana Afonso acknowledges the FCT grant 2020.04773.BD.

\section{References}

Adav, S.S., Lee, D.J., Lai, J.Y., 2008. Intergeneric coaggregation of strains isolated from phenol-degrading aerobic granules. Appl. Microbiol. Biotechnol. 79, 657661. doi:10.1007/s00253-008-1456-8.
Almstrand, R., Daims, H., Persson, F., Sörensson, F., Hermansson, M., 2013. New methods for analysis of spatial distribution and coaggregation of microbial populations in complex biofilms. Appl. Environ. Microbiol. 79, 5978-5987. doi:10. 1128/AEM.01727-13.

Andersson, D.I., Hughes, D., 2014. Microbiological effects of sublethal levels of antibiotics. Nat. Rev. Microbiol. 12, 465-478. doi:10.1038/nrmicro3270.

Arzmi, M.H., Dashper, S., Catmull, D., Cirillo, N., Reynolds, E.C., McCullough, M., 2015. Coaggregation of Candida albicans, Actinomyces naeslundii and Streptococcus mutans is Candida albicans strain dependent. FEMS Yeast Res 15. doi:10. $1093 /$ femsyr/fov038.

Assefa, A., Abunna, F., 2018. Maintenance of Fish Health in Aquaculture: Review of Epidemiological Approaches for Prevention and Control of Infectious Disease of Fish. Vet. Med. Int. doi:10.1155/2018/5432497.

Attar, N., 2016. Microbial ecology: FISHing in the oral microbiota. Nat. Rev. Microbiol. 14, 132-133. doi:10.1038/nrmicro.2016.21.

Aziz, G., Fakhar, H., ur Rahman, S., Tariq, M., Zaidi, A., 2019. An assessment of the aggregation and probiotic characteristics of Lactobacillus species isolated from native (desi) chicken gut. J. Appl. Poult. Res. 28, 846-857. doi:10.3382/JAPR/ PFZ042.

Beloin, C., Houry, A., Froment, M., Ghigo, J.-M., Henry, N., 2008. A Short-Time Scale Colloidal System Reveals Early Bacterial Adhesion Dynamics. PLoS Biol 6, e167. doi:10.1371/journal.pbio.0060167.

Bondarenko, A.S., Patmanidis, I., Alessandri, R., Souza, P.C.T., Jansen, T.L.C., De Vries, A.H., Marrink, S.J., Knoester, J., 2020. Multiscale modeling of molecular structure and optical properties of complex supramolecular aggregates. Chem. Sci. 11, 11514-11524. doi:10.1039/d0sc03110k.

Bos, R., van der Mei, H.C., Busscher, H.J., 1999. Physico-chemistry of initial microbial adhesive interactions - its mechanisms and methods for study. FEMS Microbiol. Rev. 23, 179-230. doi:10.1111/j.1574-6976.1999.tb00396.x.

Bos, R., van der Mei, H.C., Busscher, H.J., 1996. Influence of ionic strength and substratum hydrophobicity on the co-adhesion of oral microbial pairs. Microbiology 142, 2355-2361. doi:10.1099/00221287-142-9-2355.

Busscher, H.J., van der Mei, H.C., 1997. Physico-chemical interactions in initial microbial adhesion and relevance for biofilm formation. Adv. Dent. Res. 11, $24-32$. doi:10.1177/08959374970110011301.

Busscher, H., van der Mei, R., 1995. Initial microbial adhesion is a determinant for the strength of biofilm adhesion. FEMS Microbiol. Lett. 128, 229-234. doi:10. 1111/j.1574-6968.1995.tb07529.x.

Buswell, C.M., Herlihy, Y.M., Marsh, P.D., Keevil, C.W., Leach, S.A., 1997. Coaggregation amongst aquatic biofilm bacteria. J. Appl. Microbiol. 83, 477-484. doi:10. 1046/j.1365-2672.1997.00260.x.

Carvalho, I., Henriques, M., Carvalho, S., 2013. New strategies to fight bacterial adhesion. In: Méndez-Vilas, A. (Ed.), Microbial Pathogens and Strategies for Combating Them: Science, Technology and Education. Formatex, pp. 170-178.

Cazaux, J., 2005. Recent developments and new strategies in scanning electron microscopy. Journal of Microscopy. J Microsc 16-35. doi:10.1111/j.0022-2720.2005. 01414.X.

Cheng, Z., Meng., X., Wang, H., Chen, M., Li, M., 2014. Isolation and characterization of broad spectrum coaggregating bacteria from different water systems for potential use in bioaugmentation. PLoS One 9. doi:10.1371/journal.pone.0094220.

Cisar, J., Kolenbrander, P., McIntire, F., 1979. Specificity of coaggregation reactions between human oral streptococci and strains of Actinomyces viscosus or Actinomyces naeslundii. Infect. Immun. 24, 742-752.

Corno, G., Coci, M., Giardina, M., Plechuk, S., Campanile, F., Stefani, S., 2014. Antibiotics promote aggregation within aquatic bacterial communities. Front. Microbiol. 5, 297. doi:10.3389/fmicb.2014.00297.

Corno, G., Villiger, J., Pernthaler, J., 2013. Coaggregation in a microbial predator-prey system affects competition and trophic transfer efficiency. Ecology 94, 870-881. doi:10.1890/12-1652.1.

Cunha, E., Rebelo, S., Carneiro, C., Tavares, L., Carreira, L.M., Oliveira, M., 2020. A polymicrobial biofilm model for testing the antimicrobial potential of a nisinbiogel for canine periodontal disease control. BMC Vet. Res. 16, 469. doi:10.1186/ s12917-020-02646-3.

Daims, H., Purkhold, U., Bjerrum, L., Arnold, E., Wilderer, P.A., Wagner, M., 2001. Nitrification in sequencing biofilm batch reactors: Lessons from molecular approaches. In: Water Science and Technology. IWA Publishing, pp. 9-18. doi:10. 2166/wst.2001.0113.

Dang, H., Lovell, C.R., 2016. Microbial Surface Colonization and Biofilm Development in Marine. Environments. Microbiol. Mol. Biol. Rev. 80, 91-138. doi:10. 1128/mmbr.00037-15.

Davey, M.E., O’Toole, G.A., 2000. Microbial Biofilms: from. Ecology to Molecular Genetics. Microbiol. Mol. Biol. Rev. 64, 847-867. doi:10.1128/mmbr.64.4.847-867. 2000.

Davies, J., Spiegelman, G.B., Yim, G., 2006. The world of subinhibitory antibiotic concentrations. Curr. Opin. Microbiol. doi:10.1016/j.mib.2006.08.006.

De Beer, D., Stoodley, P., Dworkin, M., Falkow, S., Rosenberg, E., Schleifer, K., 2006. Microbial biofilms. In: Stackebrandt, E. (Ed.), The Prokaryotes. Springer, New YorK, USA, pp. 904-937.

de Carvalho, C.C.C.R., 2018. Marine biofilms: A successful microbial strategy with economic implications. Front. Mar. Sci. doi:10.3389/fmars.2018.00126.

de Kreuk, M.K., van Loosdrecht, M.C., 2006. Formation of Aerobic Granules with Domestic Sewage. J. Environ. Eng. 132, 694-697 https://doi.org/10.1061/(ASCE)0733-9372(2006)132:6(694).

Del Re, B., Sgorbati, B., Miglioli, M., Palenzona, D., 2000. Adhesion, autoaggregation and hydrophobicity of 13 strains of Bifidobacterium longum. Lett. Appl. Microbiol. 31, 438-442. doi:10.1046/j.1365-2672.2000.00845.x. 
Di Gioia, D., Fambrini, L., Coppini, E., Fava, F., Barberio, C., 2004. Aggregation-based cooperation during bacterial aerobic degradation of polyethoxylated nonylphenols. Res. Microbiol. 155, 761-769. doi:10.1016/j.resmic.2004.05.015.

Diaz, R.J., Rosenberg, R., 2008. Spreading dead zones and consequences for marine ecosystems. Science 15 (5891), 926-929. doi:10.1126/science.1156401, 321.

Douterelo, I., Boxall, J.B., Deines, P., Sekar, R., Fish, K.E., Biggs, C.A., 2014. Methodological approaches for studying the microbial ecology of drinking water distribution systems. Water Res doi:10.1016/j.watres.2014.07.008.

Ekmekci, H., Aslim, B., Ozturk, S., 2009. Characterization of vaginal lactobacilli coaggregation ability with Escherichia coli. Microbiol. Immunol. 53, 59-65. doi:10. 1111/j.1348-0421.2009.00115.x.

Elliott, D.R., Wilson, M., Buckley, C.M.F., Spratt, D.A., 2006. Aggregative behavior of bacteria isolated from canine dental plaque. Appl. Environ. Microbiol. 72, 52115217. doi:10.1128/AEM.01060-05.

Evans, L.V., 2000. Biofilm Control in Industrial Water Systems: Approaching old problem in New Ways. In: Biofilms. CRC Press, pp. 360-388. doi:10.1201/ 9781482284157-25.

FAO, 2017. The Global Aquaculture Summit 2017. GLOBEFISH - Inf. Anal. World Fish Trade URL http://www.fao.org/in-action/globefish/news-events/ details-news/en/c/897130/(accessed 8.14.20)

Feckler, A., Kahlert, M., Bundschuh, M., 2015. Impacts of contaminants on the ecological role of lotic biofilms. Bull. Environ. Contam. Toxicol. doi:10.1007/ s00128-015-1642-1.

Fulaz, S., Vitale, S., Quinn, L., Casey, E., 2019. Nanoparticle-Biofilm Interactions: The Role of the EPS Matrix. Trends Microbiol doi:10.1016/j.tim.2019.07.004

García-Cayuela, T., Korany, A.M., Bustos, I., Gómez de Cadiñanos, P., L., Requena, T., Peláez, C., Martínez-Cuesta, M.C., 2014. Adhesion abilities of dairy Lactobacillus plantarum strains showing an aggregation phenotype. Food Res. Int. 57, 4450. doi:10.1016/j.foodres.2014.01.010.

Geng, J., Henry, N., 2011. Short time-scale bacterial adhesion dynamics. Adv. Exp. Med. Biol. 715, 315-331. doi:10.1007/978-94-007-0940-9 20.

Giaouris, E., 2020. Application of lactic acid bacteria and their metabolites against foodborne pathogenic bacterial biofilms. In: Recent Trends in Biofilm Science and Technology. Elsevier, pp. 205-232. doi:10.1016/b978-0-12-819497-3. 00009-x

Gibbons, R.J., Nygaard, M., 1970. Interbacterial aggregation of plaque bacteria. Arch. Oral Biol. 15. doi:10.1016/0003-9969(70)90031-2.

Gilbert, P., Maira-Litran, T., McBain, A.J., Rickard, A.H., Whyte, F.W., 2002. The physiology and collective recalcitrance of microbial biofilm communities. Adv. Microb. Physiol. doi:10.1016/S0065-2911(02)46005-5

Gizem, A., 2015. General rights Management of microbial community composition, architecture and performance in autotrophic nitrogen removing bioreactors through aeration regimes. Technical University of Denmark, DTU Environment.

Gruber-Dorninger, C., Pester, M., Kitzinger, K., Savio, D.F., Loy, A., Rattei, T., Wagner, M., Daims, H., 2015. Functionally relevant diversity of closely related Nitrospira in activated sludge. ISME J 9, 643-655. doi:10.1038/ismej.2014.156.

Gujer, W., 2010. Nitrification and me - A subjective review. Water Res doi:10.1016/j. watres.2009.08.038.

Hall-Stoodley, L., Stoodley, P., 2002. Developmental regulation of microbial biofilms. Curr. Opin. Biotechnol. doi:10.1016/S0958-1669(02)00318-X.

Hede, N., Khandeparker, L., 2020. Extracellular polymeric substances mediate the coaggregation of aquatic biofilm-forming bacteria. Hydrobiologia 847, 42494272. doi:10.1007/s10750-020-04411-X.

Hendrickson, E.L., Beck, D.A.C., Miller, D.P., Wang, Q., Whiteley, M., Lamont, R.J., Hackett, M., 2017. Insights into dynamic polymicrobial synergy revealed by time-coursed. RNA-Seq. Front. Microbiol. 8. doi:10.3389/fmicb.2017.00261.

Henssge, U., Do, T., Radford, D.R., Gilbert, S.C., Clark, D., Beighton, D., 2009. Emended description of Actinomyces naeslundii and descriptions of Actinomyces oris sp. nov. and Actinomyces johnsonii sp. nov., previously identified as Actinomyces naeslundii genospecies 1, 2 and WVA 963. Int. J. Syst. Evol. Microbiol. 59, 509516. doi:10.1099/ijs.0.000950-0.

Holcombe, L.J., Patel, N., Colyer, A., Deusch, O., O’Flynn, C., Harris, S., 2014. Early canine plaque biofilms: Characterization of key bacterial interactions involved in initial colonization of enamel. PLoS One 9, e113744. doi:10.1371/journal.pone. $0113744,9,12$.

Ikuma, K., Decho, A.W., Lau, B.L.T., 2015. When nanoparticles meet biofilms - Interactions guiding the environmental fate and accumulation of nanoparticles. Front. Microbiol. doi:10.3389/fmicb.2015.00591

Ishii, S., Kosaka, T., Hori, K., Hotta, Y., Watanabe, K., 2005. Coaggregation facilitates interspecies hydrogen transfer between Pelotomaculum thermopropionicum and Methanothermobacter thermautotrophicus. Appl. Environ. Microbiol. 71, 78387845. doi:10.1128/AEM.71.12.7838-7845.2005.

Ishii, S., Kosaka, T., Hotta, Y., Watanabe, K., 2006. Simulating the contribution of coaggregation to interspecies hydrogen fluxes in syntrophic methanogenic consortia. Appl. Environ. Microbiol. 72, 5093-5096. doi:10.1128/AEM.00333-06.

Jakubovics, N., Kolenbrander, P., 2010. The road to ruin: The formation of diseaseassociated oral biofilms. Oral Dis 16, 729-739. doi:10.1111/j.1601-0825.2010. 01701.x.

Jakubovics, N.S., 2015. Intermicrobial Interactions as a Driver for Community Composition and Stratification of Oral Biofilms. J. Mol. Biol. 427, 3662-3675. doi:10. 1016/j.jmb.2015.09.022

Jiang, H., Tay, J.H., Maszenan, A.M., Tay, S.T.L., 2006. Enhanced phenol biodegradation and aerobic granulation by two coaggregating bacterial strains. Environ. Sci. Technol. 40, 6137-6142. doi:10.1021/es0609295.

Katharios-Lanwermeyer, S., Xi, C., Jakubovics, N.S., Rickard, A.H., 2014. Mini-review: Microbial coaggregation: ubiquity and implications for biofilm development. Biofouling 30, 1235-1251. doi:10.1080/08927014.2014.976206.
Kato, S., 2015. Biotechnological aspects of microbial extracellular electron transfer. Microbes Environ 30, 133-139. doi:10.1264/jsme2.ME15028.

Katsikogianni, M., Missirlis, Y.F., Harris, L., Douglas, J., 2004. Concise review of mechanisms of bacterial adhesion to biomaterials and of techniques used in estimating bacteria-material interactions. Eur. Cells Mater. 8, 37-57. doi:10.22203/eCM. v008a05.

Kerr, C., Osborn, K., Rickard, A., Robson, G., Handley, P., 2003. Biofilms in water distribution systems. In: Mara, D., Horan, N. (Eds.), Water and Wastewater Microbiology. Academic Press, Elsevier, London, pp. 757-776.

Khan, M.F., Yu, L., Tay, J.H., Achari, G., 2019. Coaggregation of bacterial communities in aerobic granulation and its application on the biodegradation of sulfolane. J. Hazard. Mater. 377, 206-214. doi:10.1016/j.jhazmat.2019.05.076.

Kolenbrander, P., 2000. Oral Microbial Communities: Biofilms, Interactions, and Genetic Systems. Annu. Rev. Microbiol. 54, 413-437. doi:10.1146/annurev.micro.54. 1.413 .

Kolenbrander, P., 1997. Oral microbiology and coaggregation. In: Shapiro, J., Dworkin, M. (Eds.), Bacteria as Multicellular Organisms. Oxford University Press, Oxford, pp. 245-269.

Kolenbrander, P., Andersen, R., Blehert, D., Egland, P., Foster, J., Palmer, R., 2002. Communication among Oral Bacteria. Microbiol. Mol. Biol. Rev. 66, 486-505. doi:10.1128/mmbr.66.3.486-505.2002.

Kolenbrander, P., Andersen, R., Clemans, D., Whittaker, C., Klier, C., 1999. Potential role of functionally similar coaggregation mediators in bacterial succession. In: Newman, H., Wilson, M. (Eds.), Dental Plaque Revisited: Oral Biofilms in Health and Disease. Bioline, Cardiff, pp. 171-186.

Kolenbrander, P., Andersen, R., Kazmerzak, K., Palmer, R., 2010. Coaggregation and coadhesion in oral biofilms. In: Community Structure and Co-Operation in Biofilms. Cambridge University Press, pp. 65-86. doi:10.1017/cbo9780511754814. 006.

Kolenbrander, P., Palmer, R., Rickard, A., Jakubovics, N., Chalmers, N., Diaz, P., 2006. Bacterial interactions and successions during plaque development. Periodontol. 42, 47-79. doi:10.1111/j.1600-0757.2006.00187.x, 2000.

Kolenbrander, P.E., 1993. Coaggregation of human oral bacteria: potential role in the accretion of dental plaque. J. Appl. Bacteriol. 74, 79S-86S. doi:10.1111/j. 1365-2672.1993.tb04344.x.

Kolenbrander, P.E., 1988. Intergeneric coaggregation among human oral bacteria and ecology of dental plaque. Annu. Rev. Microbiol. 42, 627-656. doi:10.1146/ annurev.mi.42.100188.003211.

Kolenbrander, P.E., Williams, B.L., 1981. Lactose-reversible coaggregation between oral Actinomycetes and Streptococcus sanguis. Infect. Immun. 33, 95-102. doi:10. 1128/iai.33.1.95-102.1981.

Kostelac, D., Gerić, M., Gajski, G., Markov, K., Domijan, A.M., Čanak, I., Jakopović, Ž., Svetec, I.K., Žunar, B., Frece, J., 2020. Lactic acid bacteria isolated from equid milk and their extracellular metabolites show great probiotic properties and anti-inflammatory potential. Int. Dairy J. 104828. doi:10.1016/j.idairyj.2020. 104828.

Kuan, H.S., Pönisch, W., Jülicher, F., Zaburdaev, V., 2020. Continuum theory of active phase separation in cellular aggregates. bioRxiv doi:10.1101/2020.02.26.966622.

Kwak, Y., Rhee, I.K., Shin, J.H., 2013. Application of biofilm-forming bacteria on the enhancement of organophosphorus fungicide degradation. Bioremediat. J. 17, 173-181. doi:10.1080/10889868.2013.807773.

Lazarova, V., Manem, J., 1995. Biofilm characterization and activity analysis in water and wastewater treatment. Water Res 29, 2227-2245. doi:10.1016 0043-1354(95)00054-O

Ledder, R.G., Timperley, A.S., Friswell, M.K., Macfarlane, S., McBain, A.J., 2008. Coaggregation between and among human intestinal and oral bacteria. FEMS Microbiol. Ecol. 66, 630-636. doi:10.1111/j.1574-6941.2008.00525.x.

Levin-Sparenberg, E., Shin, J.M., Hastings, E.M., Freeland, M., Segaloff, H. Rickard, A.H., Foxman, B., 2016. High-throughput quantitative method for assessing coaggregation among oral bacterial species. Lett. Appl. Microbiol. 63, 274-281. doi:10.1111/lam.12622.

Li, C., Li, Y., Cheng, X., Feng, L., Xi, C., Zhang, Y., 2013. Immobilization of Rhodococcus rhodochrous BX2 (an acetonitrile-degrading bacterium) with biofilm-forming bacteria for wastewater treatment. Bioresour. Technol. 131, 390-396. doi:10. 1016/j.biortech.2012.12.140.

Liu, Y., Wang, Z.W., Qin, L., Liu, Y.Q., Tay, J.H., 2005. Selection pressure-driven aerobic granulation in a sequencing batch reactor. Appl. Microbiol. Biotechnol. 67, 2632. doi:10.1007/s00253-004-1820-2.

Lücker, S., Schwarz, J., Gruber-Dorninger, C., Spieck, E., Wagner, M., Daims, H., 2015. Nitrotoga-like bacteria are previously unrecognized key nitrite oxidizers in fullscale wastewater treatment plants. ISME J 9, 708-720. doi:10.1038/ismej.2014. 158

Lukumbuzya, M., Schmid, M., Pjevac, P., Daims, H., 2019. A Multicolor Fluorescence in situ Hybridization Approach Using an Extended Set of Fluorophores to Visualize Microorganisms. Front. Microbiol. 10, 1383. doi:10.3389/fmicb.2019.01383.

Mahajan, A., Singh, B., Kashyap, D., Kumar, A., Mahajan, P., 2013. Interspecies communication and periodontal disease. Sci. World J. doi:10.1155/2013/765434.

Malik, A., Sakamoto, M., Hanazaki, S., Osawa, M., Suzuki, T., Tochigi, M., Kakii, K., 2003. Coaggregation among Nonflocculating Bacteria Isolated from Activated Sludge. Appl. Environ. Microbiol. 69, 6056-6063. doi:10.1128/AEM.69.10. 6056-6063.2003.

Marsh, P., Bradshaw, D., 1995. Dental plaque as a biofilm. J. Ind. Microbiol. 15, 169175. doi:10.1007/BF01569822.

Mattila-Sandholm, T., Wirtanen, G., 1992. Biofilm Formation in the Industry: A review. Food Rev. Int. 8, 573-603. doi:10.1080/87559129209540953.

McCormick, D.W., Boles, B.R., Rickard, A.H., 2011. Does it take Two to Tango? The Importance of Coaggregation in Multi-Species Biofilms. 
McIntire, F.C., Vatter, A.E., Baros, J., Arnold, J., 1978. Mechanism of coaggregation between Actinomyces viscosus T14V and Streptococcus sanguis 34. Infect. Immun. 21, 978-988. doi:10.1128/iai.21.3.978-988.1978.

Min, K.R., Rickard, A.H., 2009. Coaggregation by the freshwater bacterium Sphingomonas natatoria alters dual-species biofilm formation. Appl. Environ. Microbiol. 75, 3987-3997. doi:10.1128/AEM.02843-08.

Min, K.R., Zimmer, M.N., Rickard, A.H., 2010. Physicochemical parameters influencing coaggregation between the freshwater bacteria Sphingomonas natatoria 2.1 and Micrococcus luteus 2.13. Biofouling 26, 931-940. doi:10.1080/08927014.2010. 531128.

Mohammed, W.K., Krasnogor, N., Jakubovics, N.S., 2018. Streptococcus gordonii Challisin protease is required for sensing cell-cell contact with Actinomyces oris. FEMS Microbiol. Ecol. 94, 43. doi:10.1093/femsec/fiy043.

Mutha, N.V.R., Mohammed, W.K., Krasnogor, N., Tan, G.Y.A., Choo, S.W., Jakubovics, N.S., 2018. Transcriptional responses of Streptococcus gordonii and Fusobacterium nucleatum to coaggregation. Mol. Oral Microbiol. 33, 450-464. doi:10.1111/omi.12248

Mutha, N.V.R., Mohammed, W.K., Krasnogor, N., Tan, G.Y.A., Wee, W.Y., Li, Y., Choo, S.W., Jakubovics, N.S., 2019. Transcriptional profiling of coaggregation interactions between Streptococcus gordonii and Veillonella parvula by Dual RNASeq. Sci. Rep. 9, 1-14. doi:10.1038/s41598-019-43979-w.

Nallala, V., Jeevaratnam, K., 2018. Probiotic evaluation of antimicrobial Lactobacillus plantarum VJC38 isolated from the crop of broiler chicken. Microbiol. 87, 350362. doi:10.1134/S0026261718030062.

Niemann, H.H., Schubert, W.D., Heinz, D.W., 2004. Adhesins and invasins of pathogenic bacteria: A structural view. Microbes Infect 6, 101-112. doi:10.1016/ j.micinf.2003.11.001.

Nzila, A., Razzak, S.A., Zhu, J., 2016. Bioaugmentation: An emerging strategy of industrial wastewater treatment for reuse and discharge. Int. J. Environ. Res. Public Health. 13, 846. doi:10.3390/ijerph13090846.

Olsen, I., 2018. Organization of supragingival plaque at the micron scale. J. Oral Microbiol. 10, 1438722. doi:10.1080/20002297.2018.1438722.

Postollec, F., Norde, W., De Vries, J., Busscher, H.J., van der Mei, H.C., 2006. Interactive forces between co-aggregating and non-co-aggregating oral bacterial pairs. J. Dent. Res. 85, 231-234. doi:10.1177/154405910608500305.

Postollec, F., Norde, W., van der Mei, H., Busscher, H., 2005. Microcalorimetric study on the influence of temperature on bacterial coaggregation. J. Colloid Interface Sci. 287, 461-467. doi:10.1016/j.jcis.2005.02.030.

Pusch, M., Fiebig, I., Brettar, H., Eisenmann, H., Ellis, B.K., Kaplan, L.A., Lock, M.A., Naegeli, M.W., Traunspurger, W., 1998. The role of micro-organisms in the ecological connectivity of running waters. Freshw. Biol. 40, 453-495. doi:10.1046/j. 1365-2427.1998.00372.x

Ramalingam, B., Sekar, R., Boxall, J.B., Biggs, C.A., 2013. Aggregation and biofilm formation of bacteria isolated from domestic drinking water. Water Sci. Technol. Water Supply 13, 1016-1023. doi:10.2166/ws.2013.115.

Rao, D., Webb, J.S., Kjelleberg, S., 2005. Competitive interactions in mixed-species biofilms containing the marine bacterium Pseudoalteromonas tunicata. Appl. Environ. Microbiol. 71, 1729-1736. doi:10.1128/AEM.71.4.1729-1736.2005.

Reuben, R.C., Roy, P.C., Sarkar, S.L., Ha, S.Do, Jahid, I.K., 2019. Multispecies interactions in biofilms and implications to safety of drinking water distribution system. Microbiol. Biotechnol. Lett. doi:10.4014/mbl.1907.07007.

Rickard, A., Gilbert, P., Handley, P., 2004a. Influence of growth environment on coaggregation between freshwater biofilm bacteria. J. Appl. Microbiol. 96, 13671373. doi: $10.1111 /$ j.1365-2672.2004.02297.x

Rickard, A., Gilbert, P., High, N., Kolenbrander, P., Handley, P., 2003a. Bacterial coaggregation: An integral process in the development of multi-species biofilms. Trends Microbiol doi:10.1016/S0966-842X(02)00034-3.

Rickard, A., Leach, S., Buswell, C., High, N., Handley, P., 2000. Coaggregation between aquatic bacteria is mediated by specific-growth-phase-dependent lectinsaccharide interactions. Appl. Environ. Microbiol. 66, 431-434. doi:10.1128/AEM. 66.1.431-434.2000

Rickard, A., Leach, S., Hall, L., Buswell, C., High, N., Handley, P., 2002a. Phylogenetic relationships and coaggregation ability of freshwater biofilm bacteria. Appl. Environ. Microbiol. 68, 3644-3650. doi:10.1128/AEM.68.7.3644-3650.2002.

Rickard, A., McBain, A., Ledder, R., Handley, P., Gilbert, P., 2003b. Coaggregation between freshwater bacteria within biofilm and planktonic communities. FEMS Microbiol. Lett. 220, 133-140. doi:10.1016/S0378-1097(03)00094-6.

Rickard, A., McBain, A., Stead, A., Gilbert, P., 2004b. Shear rate moderates community diversity in freshwater biofilms. Appl. Environ. Microbiol. 70, 7426-7435. doi:10.1128/AEM.70.12.7426-7435.2004.

Rickard, A.H., Allison, D.G., Leach, S.A., Wait, R., Hough, L., High, N.J., Gilbert, P., Handley, P., 2002b. Identification of a 70-kDa coaggregation adhesin expressed by the freshwater biofilm bacterium Blastomonas natatoria 2.1.. Abstracts of the 102nd Annual Meeting of the. American Society for Microbiology, UT, USA Salt Lake City.

Rico, A., Satapornvanit, K., Haque, M.M., Min, J., Nguyen, P.T., Telfer, T.C., van den Brink, P.J., 2012. Use of chemicals and biological products in Asian aquaculture and their potential environmental risks: A critical review. Rev. Aquac. 4, 75-93. doi:10.1111/j.1753-5131.2012.01062.x.

Romaní, M., Guasch, H., Balaguer, M., 2016. Aquatic Biofilms: Ecology, Water Quality and Wastewater Treatment. Aquatic Biofilms: Ecology, Water Quality and Wastewater Treatment. Caister Academic Press, Norfolk, UK doi:10.21775/ 9781910190173

Salta, M., Wharton, J.A., Blache, Y., Stokes, K.R., Briand, J.F., 2013. Marine biofilms on artificial surfaces: Structure and dynamics. Environ. Microbiol. 15, 2879-2893. doi:10.1111/1462-2920.12186
Sánchez-Ortiz, A.C., Luna-González, A., Campa-Córdova, Á.I., Escamilla-Montes, R., Flores-Miranda, Carmen, Del, M., Mazón-Suástegui, J.M., 2015. Isolation and characterization of potential probiotic bacteria from pustulose ark (Anadara tuberculosa) suitable for shrimp farming. Lat. Am. J. Aquat. Res. 43, 123-136. doi:10.3856/vol43-issue1-fulltext-11.

Sanchez-Vizuete, P., Orgaz, B., Aymerich, S., Le Coq, D., Briandet, R., 2015. Pathogens protection against the action of disinfectants in multispecies biofilms. Front. Microbiol. 6. doi:10.3389/fmicb.2015.00705.

Sarma, S.J., Tay, J.H., 2018. Aerobic granulation for future wastewater treatment technology: Challenges ahead. Environ. Sci. Water Res. Technol. 4, 9-15. doi:10.1039/ c7ew00148g.

Sengupta, S., Chattopadhyay, M.K., Grossart, H.P., 2013. The multifaceted roles of antibiotics and antibiotic resistance in nature. Front. Microbiol. 4, 47. doi:10.3389/ fmicb.2013.00047.

Shi, L., Dong, H., Reguera, G., Beyenal, H., Lu, A., Liu, J., Yu, H.Q., Fredrickson, J.K. 2016. Extracellular electron transfer mechanisms between microorganisms and minerals. Nat. Rev. Microbiol. 14, 651-652. doi:10.1038/nrmicro.2016.93.

Simões, L., Simões, M., 2013. Biofilms in drinking water: Problems and solutions. RSC Adv doi:10.1039/c2ra22243d.

Simões, L., Simões, M., Vieira, M., 2010. Influence of the diversity of bacterial isolates from drinking water on resistance of biofilms to disinfection. Appl. Environ. Microbiol. 76, 6673-6679. doi:10.1128/AEM.00872-10.

Simões, L., Simões, M., Vieira, M., 2008. Intergeneric coaggregation among drinking water bacteria: Evidence of a role for Acinetobacter calcoaceticus as a bridging bacterium. Appl. Environ. Microbiol. 74, 1259-1263. doi:10.1128/AEM.01747-07.

Simões, L., Simões, M., Vieira, M., 2007. Biofilm interactions between distinct bacterial genera isolated from drinking water. Appl. Environ. Microbiol. 73, 61926200. doi:10.1128/AEM.00837-07.

Stevens, M.R.E., Luo, T.L., Vornhagen, J., Jakubovics, N.S., Gilsdorf, J.R., Marrs, C.F., Møretrø, T., Rickard, A.H., 2015. Coaggregation occurs between microorganisms isolated from different environments. FEMS Microbiol. Ecol. 91, 123. doi:10. 1093/femsec/fiv123.

Summers, Z.M., Fogarty, H.E., Leang, C., Franks, A.E., Malvankar, N.S., Lovley, D.R., 2010. Direct exchange of electrons within aggregates of an evolved syntrophic coculture of anaerobic bacteria. Science 330, 1413-1415. doi:10.1126/science. 1196526.

Toh, Y.S., Yeoh, S.L., Yap, I.K.S., Teh, C.S.J., Win, T.T., Tong, K.L., Chong, C.W., 2019. Role of coaggregation in the pathogenicity and prolonged colonisation of Vibrio cholerae. Med. Microbiol. Immunol. 208. doi:10.1007/S00430-019-00628-3.

Tomich, M., Mohr, C.D., 2003. Adherence and autoaggregation phenotypes of a Burkholderia cenocepacia cable pilus mutant. FEMS Microbiol. Lett. 228, 287-297. doi:10.1016/S0378-1097(03)00785-7.

Trunk, T., Khalil, S., H., C.Leo, J., 2018. Bacterial autoaggregation. AIMS Microbiol 4 , 140-164. doi:10.3934/microbiol.2018.1.140.

Underwood, G.J.C., Perkins, R.G., Consalvey, M.C., Hanlon, A.R.M., Oxborough, K., Baker, N.R., Paterson, D.M., 2005. Patterns in microphytobenthic primary productivity: Species-specific variation in migratory rhythms and photosynthetic efficiency in mixed-species biofilms. Limnol. Oceanogr. 50, 755-767. doi:10. 4319/lo.2005.50.3.0755.

Vadassery, D.H., Pillai, D., 2020. Quorum quenching potential of Enterococcus faecium QQ12 isolated from gastrointestinal tract of Oreochromis niloticus and its application as a probiotic for the control of Aeromonas hydrophila infection in goldfish Carassius auratus (Linnaeus 1758). Brazilian J. Microbiol. 51, 1333-1343. doi:10.1007/s42770-020-00230-3.

Valm, A.M., Mark Welch, J.L., Rieken, C.W., Hasegawa, Y., Sogin, M.L., Oldenbourg, R., Dewhirst, F.E., Borisy, G.G., 2011. Systems-level analysis of microbial community organization through combinatorial labeling and spectral imaging. Proc. Natl. Acad. Sci. U. S. A. 108, 4152-4157. doi:10.1073/pnas.1101134108.

Vanzieleghem, T., Couniot, N., Herman-Bausier, P., Flandre, D., Dufrêne, Y.F. Mahillon, J., 2016. Role of Ionic Strength in Staphylococcal Cell Aggregation. Langmuir 32, 7277-7283. doi:10.1021/acs.langmuir.6b00499.

Verschuere, L., Rombaut, G., Sorgeloos, P., Verstraete, W., 2000. Probiotic Bacteria as Biological Control Agents in Aquaculture. Microbiol. Mol. Biol. Rev. 64, 655-671. doi:10.1128/mmbr.64.4.655-671.2000.

Verstraeten, N., Braeken, K., Debkumari, B., Fauvart, M., Fransaer, J., Vermant, J., Michiels, J., 2008. Living on a surface: swarming and biofilm formation. Trends Microbiol doi:10.1016/j.tim.2008.07.004.

Vert, M., Doi, Y., Hellwich, K.-H., Hess, M., Hodge, P., Kubisa, P., Rinaudo, M., Schué, F., 2012. Terminology for biorelated polymers and applications (IUPAC Recommendations 2012). Pure Appl. Chem 84, 377-410. doi:10.1351/ PAC-REC-10-12-04.

Videla, H., Herrera, L., 2005. Microbiologically influenced corrosion: looking to the future. Int Microbiol 8, 169-180.

Vornhagen, J., Stevens, M., McCormick, D.W., Dowd, S.E., Eisenberg, J.N.S., Boles, B.R., Rickard, A.H., 2013. Coaggregation occurs amongst bacteria within and between biofilms in domestic showerheads. Biofouling 29, 53-68. doi:10.1080/08927014. 2012.744395.

Wagner, M., Loy, A., Nogueira, R., Purkhold, U., Lee, N., Daims, H., 2002. Microbial community composition and function in wastewater treatment plants. Int. J. Gen. Mol. Microbiol. 81, 665-680. doi:10.1023/A:1020586312170.

Weiss, E.I., Shaniztki, B., Dotan, M., Ganeshkumar, N., Kolenbrander, P.E., Metzger, Z., 2000. Attachment of Fusobacterium nucleatum PK1594 to mammalian cells and its coaggregation with periodontopathogenic bacteria are mediated by the same galactose-binding adhesin. Oral Microbiol. Immunol. 15, 371-377. doi:10.1034/j. 1399-302X.2000.150606.x. 
Weiss, E.I., Shenitzki, B., Leibusor, R., 1996. Microbial coaggregation in the oral cavity. In: Advances in Experimental Medicine and Biology. Springer New York LLC, pp. 233-240. doi:10.1007/978-1-4613-0415-9_28.

Wimpenny, J., Colasanti, R., 2004. A simple cellular automaton model for coaggregation. Biofilms 1, 369-375. doi:10.1017/s1479050505001584.

Younes, J.A., van der Mei, H.C., van den Heuvel, E., Busscher, H.J., Reid, G., 2012. Adhesion Forces and Coaggregation between Vaginal Staphylococci and Lactobacilli. PLoS One 7, e36917. doi:10.1371/journal.pone.0036917.
Yue, W., Chen, M., Cheng, Z., Xie, L., Li, M., 2018. Bioaugmentation of strain Methylobacterium sp. C1 towards p-nitrophenol removal with broad spectrum coaggregating bacteria in sequencing batch biofilm reactors. J. Hazard. Mater. 344, 431-440. doi:10.1016/j.jhazmat.2017.10.039.

Zhang, W., Liu, M., Dai, X., 2013. Biological characteristics and probiotic effect of Leuconostoc lactis strain isolated from the intestine of black porgy fish. Brazilian J. Microbiol. 44, 685-691. doi:10.1590/S1517-83822013005000053. 